\title{
Gentlemen, gentrification, and land-ownership in Leicestershire
}

\author{
By Pierre Marshall \\ ORCiD 0000-0001-9245-7670 \\ Student № 189041686
}

September 25, 2019

$\sim 12,296$ words

A thesis submitted to the School of Geography, Geology and the Environment, University of Leicester in partial fulfilment of the requirements for the degree of Master of Science.

In submitting this dissertation, I confirm that it is my own work. 


\section{Abstract}

This thesis discusses the changes to the Prestwold estate in Leicestershire, directed by select members of the Packe family. It argues that these changes were examples of gentrification and they reflected the adaption of the gentry to capitalist society.

\section{Contents}

1 Introduction $\quad 2$

2 Literature review $\quad 7$

3 Methodology 18

4 Origins of the Packe estate 20

5 Aristocratic consumption 26

6 Entrepreneurial gentrification 35

7 Conclusion $\quad 45$

$\begin{array}{ll}\text { References } & 47\end{array}$

\section{Acknowledgements}

This dissertation was written under a studentship jointly funded by the James Hutton Institute and the Economic and Social Research Council. It was supervised by Martin Phillips, who provided useful guidance and comments throughout. I would also like to thank my family - Matthieu, Christine, and Peter Marshall for their moral support. 


\section{Introduction}

The bourgeoisie has subjected the country to the rule of the towns.

Karl Marx, The Communist Manifesto

This dissertation traces the history of the Prestwold estate and the Packe family who claimed it as their seat. The estate is in northern Leicestershire, it comprises a main hall and a large park, surrounded by three villages - Burton on the Wolds, Hoton, and Wymeswold. In particular, this dissertation will examine the history of the estate through three figures: Christopher Packe who acquired the estate during the English Civil War, Charles Packe II who brought the estate to financial ruin, and Charles William Packe who attempted to rescue the estate before closing the hall and moving to Dorset.

\subsection{Research aims}

The research was primarily motivated by a series of questions about the character of land-ownership and the constitution of the gentry.

- What motivated entrepreneurs to buy land, and invest in landed estates?

- When land-owners sought to develop their estates, what form did that development take?

- How did development reflect the adaption of established elites to capitalist advance?

Beneath these questions lies the problem of class power and its foundation in the control of capital and control of land. How does 
land-ownership and rentierism influence the bourgeoisie? Does land-ownership exacerbate contradictions between class power and the force of the market? This debate demands an examination of continued existence and perpetuation of aristocratic families alongside the construction of capitalism in Britain. The line of argument pursued in this dissertation refers to how the alternative logic of territorial control adapted itself to a modern logic of capital accumulation and market competition. Some of the noble families dug mines and built workshops on the edges of their estates (Daniels 1993, pp. 82-89); ${ }^{1}$ and on the other side bourgeois factory-owners invested their profits in buying estates and country houses.

The figure of the gentleman was originally derived as a feudal rank, part of a distributed system of English government which relied on local warlords to govern their own fiefdoms in the name of the Crown. The gentlemen were officers in the local militias, and they were more specifically defined as those who had the right to carry a sword without permission (Hill 1969, p. 30). So, we see that the gentleman had a position in a social system whose mode of reproduction relied primarily on the use of force. Otherwise put, under feudalism the extraction of value from labour was conducted through 'extra-economic' means. By contrast, capitalism is characterised by accumulation and the extraction of value through economic means. These economic means of extraction and accumulation are won through gains in productivity, driven by market competition (Wood 2002, p. 53).

Nevertheless, all class societies and rely to some extent on the use of force to exert control over production. So, the relationship between economic and extra-economic compulsion is a not a hard binary distinction. This has implications for how we understand the landed gentry, whose control over land gives them a special power of monopoly. Rental revenue represents a form of value extraction which sits one step removed from production. It raises an issue, where we have to ask to what extent the land-owner is relying on

\footnotetext{
${ }^{1}$ The quarries near Montsorrel are examples of this.
} 
monopoly power to extract value from productive activity within and around their land-holding.

These questions provide a theoretical background to both contemporary and historical expressions of gentrification. The Prestwold estate was chosen initially for study due to the obvious changes in the landscape. The area has undergone several transformations: from wooded forest, to use as an air base in the Second World War, to the present day where the area now hosts one of the country's largest solar farms (Jones et al. 2014, p. 178), a racing track, an industrial estate, and sees occasional use as a festival site. The fringes of the estate are also subject to efforts by property developers to acquire land for housing development. Burton on the Wolds is the stage of a conflict between residents and developers, which is conducted through the local planning committees and visible in protest signs posted up around the village.

It was the intention of this research to study the estate over time, which might serve as the backdrop for a future study of contemporary changes around Prestwold. The second aim of this research was to bridge the gap between historical analysis of the gentry, and a contemporary analysis of gentrification. 


\subsection{Locating Prestwold}

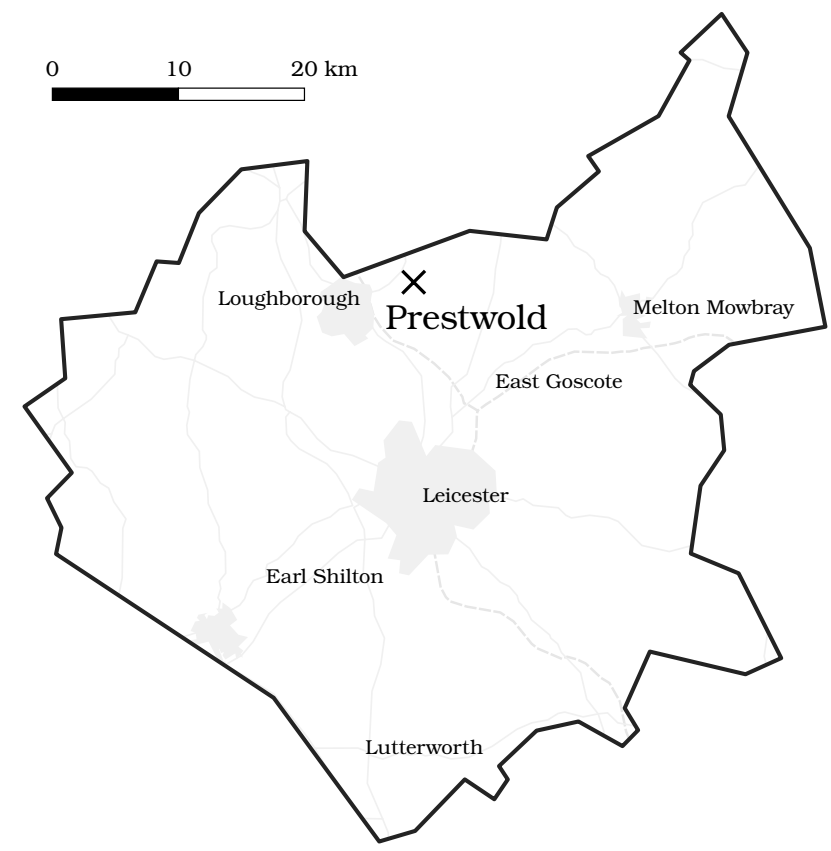

Figure 1: Prestwold located within Leicestershire, at a scale of 1:530,000.

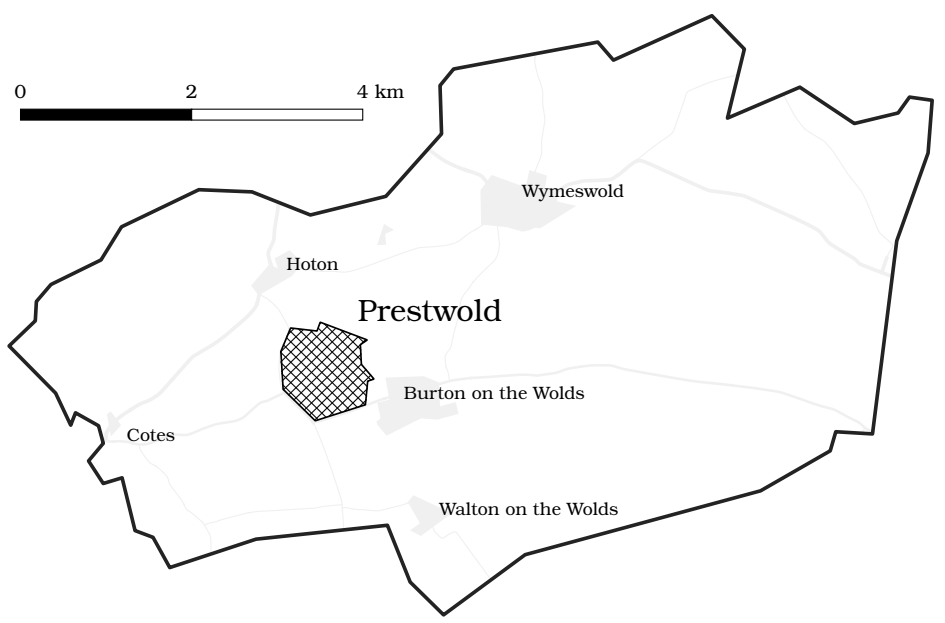

Figure 2: Prestwold located within the Wolds, at a scale of 1:70,000. 


\subsection{Defining gentrification}

Use of the term 'gentrification' is often traced back to Ruth Glass, who studied social change in London. She first referred to gentrification in the following passage from a report on urban change in London:

One by one, many of the working class quarters of London have been invaded by the middle classes - upper and lower. [...]

Once this process of 'gentrification' starts in a district, it goes on rapidly until all or most of the original working class occupiers are displaced and the whole social character of the district is changed (Glass 1964, p. xviii).

From Glass's description of gentrification, the concept refers to the shifting social character of an area. Gentrification has been described in similarly broad terms as a series of conditions which produce "dynamics of regeneration and population change" (Lees 2019, p. 10), or alternatively as "socioeconomic upgrading" (Esposito 2014, pp. 2,5; Vigdor et al. 2002, p. 174), or in the case of rural gentrification: 'rural social change' (Phillips et al. 2013, p. 227). These all identify the effects of gentrification as a form of sociospatial shift, yet there is significant debate over the causes and context of this social change. The effects of gentrification can also be thought of as a series of linked processes: a new group arrives in an area, subsequently there's a change in the (built) environment (N. Smith and LeFaivre 1984, p. 48), and this in turn is followed by displacement (Laura 2019). 


\section{Literature review}

Neil Smith emphasises the rent gap theory, explained as the difference between "actual and potential land values in a given location" (N. Smith 1987, p. 463). The rent gap attracts capital to move in, close the gap and realise the potential higher land value. This is, according to Smith, one of the motivating forces of gentrification as capital movement. However, Smith is also careful not to limit gentrification to an exclusively economic process, arguing that it goes along with a range of transformations which make up the 'restructuring of the city' (ibid., p. 464). As an explanation for this, Tom Slater notes that capital does not automatically flow into the areas where the rent gap is greatest, and investment is often purposefully withheld from areas of extraordinarily low land value (Slater 2017, pp. 85,87-90). This deliberate running down of neighbourhoods not only widens the rent gap, it also prepares the conditions for future displacement. On the other hand, existing landlords may resist new development so as to uphold a position of monopoly rents (Harvey 1976, p. 269).

Smith accepts the idea that gentrification goes beyond a neutral or technical phenomenon, and it must be read within a political context. Slater has argued for a critical outlook on gentrification, and he points out that Ruth Glass was sensitive to 'social justice' (Slater 2009). In the piece where she first introduces gentrification, Glass specifically calls out the weakening of urban planning, empowerment of property developers, real-estate speculation, the loosening of rent controls, rising property values (Glass 1964, p. xx). These tendencies were all associated by Glass with gentrification, and they're not so much the actions of autonomous market forces as deliberate political choices. They emerge from municipal ordinances, regeneration strategies, and the relationships between property developers and local government. For these critical perspectives on gentrification, it's important to understand the role of the state (Lukens 2019, pp. 9-10), as well as the social dynamics which inform capital movement. For example, in US cities such as Boston or Philadelphia (Legates et al. 1986, p. 195; N. Smith 1996, 
p. 139), gentrification takes on a more overtly racial dimension because it conforms to the particular social history and characteristics of those cities.

Alongside explicitly class-based displacement, David Harvey (2008, pp. 28,31-33, 2013, p. 4) connects gentrification to the idea of the 'right to the city.' Following Harvey's argument, gentrification can be taken both as an issue of housing allocation, as well as feeding into a broader issue of control over public space, which itself has roots in earlier conflicts over enclosure of the commons, and land access rights (Grey et al. 2019, pp. 60-62). Even the term gentrification invokes the spirit of the landed gentry, and all its association with enclosure (Gavroche 2015). By framing it in these terms we can trace the historical experiences of enclosure and primitive accumulation, through to 'accumulation by dispossession' and the contemporary neoliberal project to commodify the landscape (Harvey 2005, pp. 137-149). Gentrification stretches from the early agents of capital who chased commoners off their lands, to modern gated communities, poor doors, and the adoption of hostile architecture in cities.

One of the crucial preconditions for capitalist transformation in the countryside was the creation of land as an object of enclosure. Before the advent of capitalism, commoners and free men held rights over the land, many of which were legally codified in the Charter of the Forest in 1217. Butlin (1982, p. 32) refers to land in this condition as "a repository of use-rights, which interlocked with an inherited grid of customs and controls within which rights are exercised." The creation of enclosed land decoupled it from its ancient rights, and ascribed almost all privileges over the land to a single proprietor. This process is discussed in section 4 in relation to the actions of Christopher Packe. In a simlar vein, Harvey (2019a) argues that neoliberal 'urbanism' (Dunford et al. 1983, p. 79) constitutes a shift in land values, from use value to commercial value or exchange value. It entails the commodification of the landscape. The struggles over the 'right to the city' revolve around monetary land value, although they also face the question of what the city is for and what it means to the people who live in it. Differ- 
ent forms of value correspond with different configurations of class power embedded in the landscape. To its inhabitants, the city exists as an assemblage of amenities for work, rest, and leisure. Alternatively, the city exists as a lumpy pattern of financial acclivations, its uneven surface pockmarked with concentrations of deprivation alongside concentrations of wealth. Harvey makes this point when comparing postwar social-democratic approaches to housing with the neoliberal approach of the 1980s. Houses accrued value not in their role as comfortable homes, but in their role as financial assets (Harvey 2019a). In this way gentrification occurs as part of a neoliberal restructuring of space in which "the quest for profit takes precedence over the human need of shelter" (Slater 2017, p. 88). Harvey is clear in describing neoliberalism as a class project (Bastani 2017, 35:43; Ward 2019, p. 69; Risager 2016), whose driving purpose is to enforce the power of capital vis-à-vis labour. Gentrification can be understood in similar terms, as a political process which intervenes to shape the landscape according to class imperatives. The state assists capital by creating desirable places for investment, and it creates the conditions for gentrification (Slater 2017, p. 89; N. Smith 1979, p. 546).

Gentrification has been described through its underlying economic dynamics, the movement of capital through space. Harvey describes a process known of as the spatial fix (Harvey 2019b, 2005, pp. 115-122; Herod 2019), through which surplus capital expands geographically to seek more profitable areas for investment. Capital accumulates, then over-accumulates and is forced to move. With every outward leap, the moment of crisis is deferred, but never resolved, and so capital must remain in constant motion. Harvey and Herod (1991, p. 388, 2003, pp. 114-116) place the operation of capitalism alongside a territorial logic, a recognition that capitalism exists within a spatial order. Gentrification can be expressed through this process of capital movement; as investment flows into an area, rents increase, and those without the money to meet the increased cost are forced to move. 


\subsection{Rural gentrification}

This dissertation is concerned with rural gentrification, and there are points in which the characteristics of rural society diverge from the original identification of gentrification in an urban context. In order to understand why rural gentrification should be studied separately from urban gentrification, we first have to understand what distinguishes the rural from the urban.

For the purposes of social science research, there are statistical definitions of what constitutes a 'rural area.' The US Department of Agriculture refers to three methodologies it uses for identifying rural areas (Cromartie et al. 2008), these are:

- Administrative distinctions, based on local government zones which cover a defined jurisdiction and sit within an administrative hierarchy. These can be townships, counties, or other bodies such as school districts or electoral precincts.

- Land-use distinctions, based on how much of an area is taken up by built-up development. In this case rural areas are those mostly covered in open fields, forests, or features of a nonurban environment.

- Economic distinctions, based on the sphere of influence of cities as market centres. In this case rural areas are those outside the economic reach of an urban centre. In the USA these economic extensions of cities are referred to as 'metropolitan areas,' made up of the commuter belts which surround urban zones. This particular formation can be explained as a historical compromise born out of the way suburban development cut off suburbia (and its relatively affluent tax-payers) beyond the administrative boundaries of the city.

For some of its programmes the USDA classifies as rural any area which is not a 'named place' (ibid.). These un-named places are effectively empty, in that they include only settlements which 
are too small or too dispersed to be recognised as organised communities. As a last resort, rural areas are simply anywhere which is not distinctively urban, the non-urban. This is the same logic by which rural gentrification can be spoken of as "non-inner city gentrification' (Gonen 2004).

In Britain, the University of Sheffield was commissioned by various government bodies to draw up a methodology for Rural Urban Classification (Bibby and Brindley 2013). The resulting report suggests classifying areas according to size and population density profiles. An earlier report by Bibby and Shepherd also mentions a range of classifications, which correspond to different settlement types such as village envelopes, small towns, hamlets, peri-urban areas, and scattered dwellings (Bibby and Shepherd 2005, p. 13). These are all rural areas, but they don't follow a common spatial organisation or structure. A $19^{\text {th }}$ Century mining village contains dense housing, with activity centred around the pit, whereas a medieval farming village is composed of cottages strung out along a road, with long gardens extending outwards from the backs of the houses (Roberts 1996, pp. 4-5,95). Furthermore, when classifying by population alone, the point of urban-rural threshold varies widely between countries; in Iceland the cutoff point for a rural settlement is 200 people, while in Japan the same cutoff point is 50,000 people (ibid., p. 9). Thus what defines rurality is dependent on cultural norms, and the concept is relative to social expectations.

Aside from demonstrating the blurriness of the distinction between urban and rural, these reports are limited by trying to describe rurality exclusively in quantitative terms (Bibby and Brindley 2013, pp. 6-8). Instead, the experience of rurality is something which is socially and culturally constructed, and through this is made up of intangible or imagined qualities. The maintenance of a sharp binary distinction between rural and urban (Inwood et al. 2013) can be considered problematic, especially where peri-urban areas are taken into account. While understanding rural society as distinct from urban society, it nonetheless exists at the end of a continuum, and between the city and the country is a zone of am- 
biguity. Occasionally, spaces of rurality emerge within the city, and through suburban sprawl the city reaches into the countryside.

Rural gentrification has been theorised separately from urban gentrification, generally placing greater emphasis on the production of rural experiences, and improvement of the land in terms of aesthetic or cultural qualities (Yang et al. 2018, p. 2). Rural gentrification has also been identified alongside a process of deagrarianisation, or the relative expansion of alternative forms of land-use (Hsu 2019, pp. 40-41). This could involve the subsumption of agrarian capital by financial capital, or it could be part of a cultural effort to redefine the valorisation of land beyond its productive capacity for agricultural or industrial uses. For example, there is a section of the rural gentrification literature which specifically discusses these shifting forms of value in relation to neoproductivist and post-productivist approaches to agriculture (Wilson 2001, pp. 81-83).

\subsection{Consumption/production debate}

The causal explanations for gentrification are contested, (Gale 2019) and there is a debate over whether gentrification is driven by production or consumption. Slater (2002) summarised supply-side and demand-side explanations, see appendix $\mathrm{C}$ for a reproduction of his comparison table.

Supply-side explanations tend to come from a political-economy perspective, they emphasise the movement of capital, the role of the state and the market, and the theory of the rent gap. They understand gentrification as a class project, whose workings can be analysed through the study of Marxism. Their methods tend to be quantitative, relying on maps of land value, sales and price paid data which reveals the financial reality of capital movement. Demand-side explanations for their part tend to come from a cultural sociology perspective. They emphasise consumer preference, individual agency, the values and cultural imaginaries of a 'middle- 
class.' They are aligned with the cultural turn in human geography, and are associated with qualitative methods - interviews, ethnography, participant observation, as well as creative methods such as photovoice.

Neil Smith remains wary of committing exclusively to either approach, concluding a dialogue with David Ley by asserting that "it should now be evident that the relationship between consumption and production is crucial to explaining gentrification" (N. Smith 1987, p. 464). He still believes that the 'restructuring of the city' is driven by the needs of capital, however he recognises that this is influenced and accompanied by a shift in middle-class values ( $\mathrm{N}$. Smith 1979, p. 547).

\subsection{The problem of land}

One of the debates around the landed or territorial element of gentrification derives from a problem described by Adam Smith, who commented that "merchants are commonly ambitious of becoming country gentlemen" (A. Smith 1977, p. 538; cited in F. Thompson 2001 , p. 9, 1994, p. 15). In various instances it was observed that industrialists, merchants, financiers, and wealthy burghers, had a tendency to invest in landed estates. This was a curious tendency because the emergence of these groups was a product of capitalist development, which in turn represented a rupture with feudalism. Meanwhile feudal society in Britain had been built upon relations with the land, and all the institutions of the feudal state were connected to land-ownership (Polanyi 2002, pp. 72-73). The point of divergence with capitalist land-ownership is that feudalism relied upon extra-economic systems of control, rather than ownership of land as a commodity. However, feudal systems of control were nonetheless drawn from the particular characteristic of land as the territorial basis for production. Although feudalism as a mode of production no longer exists in Britain in any significant way, elements of pre-capitalist social order remain, and these co-exist with capitalist order. This was troubling to Smith because it put into 
question the construction of the bourgeoisie as the protagonist of capitalism, and as a revolutionary class. Instead of overthrowing landed interests, the rising figures of industry or finance came to an accommodation and to some extent fused with the existing landed gentry by buying country estates or marrying into a noble family. For example, F. Thompson (1994, pp. 169-170) argued that the social separation between aristocrat and bourgeois landowners had never been particularly significant. However for Thompson this observation on its own did not amount to a flaw or an issue in capitalist development.

According to Hobsbawm, there is a more wavering relationship between the entrepreneur and the landed gentry. Their interests come into opposition, and they reconcile, depending on the social circumstances. For example, the conflict around the English Corn Laws brought to the surface latent tensions between grain merchants, industrial capitalists, and rural landowners. Within the rural-urban divide, farm workers were pitted against the urban proletariat. However, the same conflict also featured moments where competing groups came together within and across class lines (Hobsbawm 1969, p. 77). A similar version of this process also exists in a contemporary context, where gentrification invokes a political alliance of the 'middle class' and large land-owning property developers (Ward 2019, pp. 87-88,95,120). Like the previous examples, this alliance is based on a coincidence of landed interests and those of an aspirational upwardly-mobile group. Although again, the relationship is a wavering one, the alliance is contingent up to the point at which land values rise beyond the capacities of the middle class. Beyond this point, gentrification moves up the scale to 'supergentrification,' and middle class elements will find themselves subject to displacement. And so, there are moments of convergence between the producers and consumers of gentrified landscapes, but their interests merely coincide temporarily.

Returning to Smith's problem, Heley (2010, pp. 321,327-328) observed what he referred to as the 'new squirearchy,' a contemporary cohort of rural gentrifiers. Heley's subjects were issued from urban backgrounds in business and corporate finance, they built 
their careers around organisational or managerial positions, and then sought to 'become country gentlemen.' Although the historical context is different, the figure of the city financier who returns to the countryside is a recurring theme. What changes is the nature of the countryside retreat, and the perpetual re-imagining of the rural landscape as a terrain of recreation or consumption. The core theoretical problem of land-ownership also reoccurs where different factions of capital are highly concentrated in the same area. For example, the San Francisco Bay Area is the site of political tensions between venture capitalists and startup entrepreneurs on the one hand, and property owners on the other. Startups and lowpaid tech workers seeking cheap office space and accommodation are put in conflict with landowners seeking to extract greater rents. There are also interesting points of interaction and collaboration between these factions of capital. Innovations such a AirBNB serve to commodify unproductive space in the form of spare rooms, and expose these to the market. They represent an alliance of landlords and venture capital, however they also seek to extract a portion of the rent and establish their own monopoly position as a platform for distributing and allocating spare rooms.

Land has unique qualities or "idiosyncracies" which distinguish it from other forms of capital (Ward and Aalbers 2016, p. 1762; Bartley 2019, pp. 5-6). These qualities confer upon the owner of land a degree of monopoly power; and David Harvey refers to this:

Conflicts that focus on the built environment exhibit certain peculiar characteristics because the monopoly power conferred by private property arrangements generates not only the power to appropriate rent but also yields to the owners command over a "natural monopoly" in space. The fixed and immobile character of the built environment entails the production and use of commodities under conditions of spatial monopolistic competition with strong "neighbourhood"; or "externality"; effects (Harvey 1976, p. 268). 
For these reasons, land-ownership deserves special attention: is fixed in place, it is in limited supply, it can be physically enclosed, and its value can change based on changes to its surrounding environment. Furthermore, land is a crucial factor in production, and so combined with its unique qualities, control of land allows for a measure of control over production independent from capital or labour. Aside from its historical associations with feudal structures, it's this independent monopoly power which makes land so problematic to proponents of entrepreneurial capital such as Adam Smith.

\subsection{The middle class}

We cannot discuss the question of class displacement without engaging with the debates around class, and the middle class in particular as both the victims and the agents of gentrification. Henri Lefebvre complains that bourgeois is unknown to studies of sociology which, to him were limited to studying the popular mass, the working class. He writes that "rarely does the sociologist dare to lift his eyes towards the masters - the dominant class, to peer and uncover their hidden reality" (Lefebvre 1971, p. 165). To Lefebvre, the Marxist-Leninist definitions of class remain 'solid' - however they fail to explain sociological attitudes, the behaviours, motivations and conscience of a class (Lefebvre 1971, p. 167; Castree et al. 2004, p. 52).

Lefebvre gives the example of the way a bourgeois family looks at a house. For the bourgeois (and historically, the gentry) the house is the seat of the family, and headquarters of the family enterprise. For the noble families whose names are rooted in a long lineage, there is a point of origin, the one great ancestor, whose portrait is displayed prominently in the mansion. Lefebvre comments that the bourgeois identifies with this legacy, it makes him proud, and we can understand this pride as the 'spirit' of the bourgeoisie (Lefebvre 1971, pp. 168-169). There is a process of fusion, between the bourgeoisie and the aristocracy, between the industrial and finan- 
cial bourgeoisie, all merge and overlap, however the original distinctions leave 'traces' in the attitudes and behaviours of classes and class fractions (Lefebvre 1971, p. 165). The Packe family, the major subject of this dissertation, has an origin in the figure of Christopher Packe. Christopher Packe originally bought the estate, and Anthony Packe's biography of him is titled Our Founding Ancestor; just as Lefebvre describes, the great family portraits are still displayed in Prestwold Hall (Hussey 1959a,c). And so, although the gentry adapts to capitalist society, there are these traces which remain in the family title, the estate, and the construction of a hereditary lineage. 


\section{Methodology}

The most substantive data collected for this dissertation comes from archival research in the Leicestershire Local Records Office. The archival sources came in the form of various ephemera - accounts, maps, estate surveys, newspaper clippings and parish records. The documents deposited in the archive are from the Packe family's personal collection, and so they give an insider perspective into the life of the family. The collection is comprehensive, it covers multiple family members across successive generations, however it was difficult to pull together a consistent chronology or central narrative from disjointed events. More generally, this research involves 'rethinking' the actions of the lords of Prestwold, stepping through the thought process which led to particular actions (Guelke 1982, pp. 38-41). There is a process of interpretation, which can only be as solid at the empirical evidence it is derived from. This means that, in parts where the historical evidence is missing or incomplete, this dissertation has turned to theory for explanation.

It's also necessary to be aware of the bias of the source material, particularly around the accounts which promote a benevolent image of the Packe family's actions. For example, this dissertation makes use of Anthony Packe's biography of Christopher Packe. In the text, Anthony Packe rhetorically justifies the expropriation of Prestwold during the English Civil War as a legitimate handover of property, and not as an act of republican vengeance. Another bias stood out when putting together the family lineage in section 4.2; the ahnentafels and family trees contained full information for the men of the family, but the women were often only listed with their dates of marriage. This reflects the principle of primogeniture, and the emphasis on establishing a chain of (male) succession, rather than a broad genealogy of the whole family.

Archival research was supplemented by visits to Prestwold and Burton on the Wolds. Part of this involved an amateur ground survey and mapping of Burton and its surroundings, however this effort was put on hold once the project moved to focus on Prest- 
wold. There was some value in the journeys themselves, on repeated weekends travelling out from Leicester by bicycle or by foot and by bus. These journeys gave a sense of the distance between Leicester and Loughborough, and how that distance would have been experienced by those travelling along $19^{\text {th }}$ Century transport \& distribution networks (Everitt 1973, p. 236).

\subsection{Returning the countryside to history}

This dissertation was motivated by a methodological approach which seeks to engage with the countryside as a site of discord and rupture. Despite the original emergence of capitalism in the English countryside (Wood 2002), urbanisation is associated with capitalist development. The urban proletariat occupies a vaunted position, set above the rural worker or small-holding farmer. Meanwhile, agrarian politics lends itself to populism, it is open to class alliances and united fronts (Borras 2019). This attitude can lead to a dismissal of the English rural radical tradition as a premature or primitive development, as something insufficiently modern to warrant revolutionary potential.

Rural gentrification plays a role not only in displacing classes physically, but also in divorcing areas from their history of class struggle. The landscape of the rural idyll cannot exist side-by-side with the landscape of production and all its attendant social history (Slater 2006, p. 740). Culturally hegemonic representations of the countryside obscure class fractures (Mingay 1990, p. 141), and what Newby (1977, p. 46) referred to as the 'dark village' (cited in Phillips 1994, p. 102). For example, the Lake District is the site of picturesque natural amenities and contains valuable 'recreational resources' (Nelson et al. 2010, p. 345). Yet the same area also suffers from high rates of poverty, loss of jobs, the cancellation of bus services and the closure of medical clinics (Yeginsu et al. 2019). Therefore, to deconstruct and question romantic representations of rural idyll necessitates a return to a class perspective (Phibbs 2018, p. 12; Williams 1973). 


\section{Origins of the Packe estate}

This section will discuss the point at which Prestwold came into possession of the Packe family. The purchase of the area marks the entry of the Packe family into the ranks of the landed gentry, as well as demonstrating the social context for that transition.

The lordship of Prestwold and Cotes was bought from Sir Henry Skipwith by Christopher Packe on $12^{\text {th }}$ February 1649 (DE3969/51 Packe 1976, pp. 20,26; Farnham 1931, pp. 8-9). Christopher Packe's initial purchase of the lordship did not give him full possession of the estate, and this causes confusion in different accounts over the moment of transaction. In 1653 Christopher Packe bought the land of the estate for $£ 8,174$ and beyond that moment his acquisition of the estate was complete, as he owned both the land and the title (Shaw et al. 2005, pp. 8-9). The process of purchase is significant firstly due to the discrepancy between buying the lordship and buying the land, and secondly because it was recorded and understood as a financial transaction. For the first part, it demonstrates a formal separation of land-ownership from feudal privileges, which was crucial for the development of capitalist relations. When Christopher Packe bought Prestwold, he entered into a new and exclusive form of land-ownership which was free of ties to the crown, and did not come with obligations to share rights with the local commoners or the clergy (Wood 2002, pp. 114-115; Hill 1969, pp. 146-149). For the second part, the land was bought - it was not inherited or acquired by marriage or given as a gift from the king. Again, this deserves mention as a special and historically contingent form of land-ownership. The buying and selling of land was prohibited following the restoration of the monarchy in 1660 (Hill 1969, p. 14).

While the form of land-ownership was indicative of rationalised capitalist development, the circumstances surrounding the purchase suggest the presence of an extra-economic context. The purchase took place in the period of the English Civil War, and political conditions may have forced or coerced Henry Skipwith into 
selling his estate. Skipwith was openly sympathetic to the Royalist cause; he had hosted Charles I at Cotes on $28^{\text {th }}$ May 1645 in the run-up to the Battle of Naseby (Shaw et al. 2005, p. 9; Farnham 1931, p. 9; Hussey 1959a). After the war, Skipwith was subject to a 'composition fine' of $£ 1,114$ (Farnham 1931, p. 8) - this fine was a form of settlement levied against those who had opposed Parliament. Meanwhile, Packe was sympathetic to Parliament, he was involved in the New Model Army from 1647 to 1649, and as an alderman he had participated in officially declaring the abolition of the monarchy (Farnham 1931, p. 9; Nichols 1800, p. 354).

Packe's purchase of the estate then can be interpreted as a reward for his loyalty to Parliament, and Prestwold was "forfeit" (Shaw et al. 2005, p. 9) as the spoils of war. We could take this further, to understand that the post-war settlement reflected a continuity of political struggle. As Skipwith was a royalist, the transfer of Prestwold to Packe had the effect of removing an avowedly hostile partisan of the ancien régime from his seat of power. Framed in that way, Packe's takeover of Skipwith's estate was not only an act of patronage or a reward for loyalty. It drove through the imperatives of Parliament, as the expression of a radical project to overthrow the reactionary nobility. The intentions of this act become clearer when we see that across the country, the Committees for Sequestration raised around $£ 1.5$ million in fines against 'delinquent' royalists, sometimes accompanied by direct expropriation of their land (Hill 1969, p. 148). There was a vast nationwide exchange of property in which the royalists were systematically dispossessed, and Packe was part of that movement.

The biography of Christoper Packe written by Anthony Packe (1976) dismisses the connection between the purchase of the estate and the Civil War. He frames the purchase of the estate as a legitimate business deal, emphasising the fact that Skipwith suffered from 'financial embarrassment' (ibid., p. 20), although he recognises that Skipwith's financial situation was made worse by having to pay the composition fine. Anthony Packe is correct to point out that the transfer of land-ownership did occur by economic means, as the Prestwold estate was never violently expropriated. However, 
the political conditions surrounding the purchase cannot be ignored. Anthony Packe also had a personal stake in making sure that his family name wasn't marred by accusations that the Prestwold estate might have been 'stolen' during the Civil War; which explains his insistence on establishing the legitimacy of the purchase.

\subsection{Christopher Packe as an entrepreneur}

Christopher Packe had inherited money from his father, Thomas Packe, who was a prominent businessman in Finchley (Millennium Book 2000, DE6289). Christopher built his own fortune as a wool merchant in Kettering,(Farnham 1931, p. 9) and Anthony Packe describes him as a "self-made London business man" who followed "the time honoured tradition of making his fortune in commerce and then using that fortune to become a land owner and join the ranks of the gentry" (Packe 1976, p. 17). Although he did inherit wealth, he was not of a noble background, he rose up through a system of merchant guilds and various forms of 'public employment.' Through his career he held positions as an Alderman, Sheriff, Customs official, Governor of the Company of Merchant Adventurers, Mayor of London, and finally Member of Parliament under Cromwell (Stephen 1895, pp. 28-30; Nichols 1800, pp. 354-355). He came to be a man of influence through his association with the state and with commercial interests, rather than through association with a particular noble family background. His career also highlights the sophistication and relative autonomy of the state in the $17^{\text {th }}$ Century. For example, his role as a customs officer gave him power over trade and merchant activity, and while he was 'Treasurer at War', he was permitted to take a cut of the transactions he oversaw (Cross 1993, p. 2). These positions created a space within the state which operated independently of aristocratic interests.

Christopher Packe's record in parliament brings up another dimension to his actions as an agent of early entrepreneurial activity. He had participated in demanding the abolition of the monarchy 
in 1649, yet eight years later he led a proposal to crown Cromwell as a new monarch ( $\mathrm{J}$. Thompson 1849 , p. 414). On $23^{\text {rd }}$ February 1657, he presented a paper to parliament on the 'settlement of the nation', which called on Cromwell to "assume the name of King" (Packe 1976, p. 11). The proposal triggered loud opposition from the radical republican factions in parliament, they declared it an unparliamentary proceeding and dragged Packe out his seat (DE3969/17/7-8).

The episode in parliament highlights the contradictions within the civil war as a revolutionary process. Through this, Christopher Packe displays an allegiance to his class. A bureaucrat from a merchant background, he opposes the king, but stands against the republican current which might threaten his interests. These tensions, and the contested political character of the Civil War, go some way to explaining why Christopher Packe was able to transition so easily into the landed gentry. He kept the estate after the restoration of the monarchy; he was only stripped of his knighthood, banned from holding public office, and allowed to retire in peace. Meanwhile, Henry Skipwith went to British America and established the Prestwold plantation in the state of Virginia (DE3969/17/2).

\subsection{Packe family lineage}

This family lineage shows how the estate was passed down through successive generations from 1650 to 2019 .

Generation 1 Sir Christopher PACKE was born in 1593, married his second wife Anne EDmonds in 1651, and died on 27 ${ }^{\text {th }}$ May 1682. They had issue Christopher, and Simon (b. $1654 \mathrm{~d}$. 1701).

Generation 2 Christopher PACKE was born in 1643, married Jane Clifton and died on $8^{\text {th }}$ September 1699. They had issue Clifton, and Charles (d. 1751). 
Generation 3 Clifton PACKE was born in 1674, married Penelope BATE, and died on $9^{\text {th }}$ June 1707 . They had issue Charles.

Generation 4 Charles PACKE was born in 1701, he married Rebecca HARvey, and died in August 1735. They had issue Charles James, and Elizabeth Rebecca.

Generation 5 Charles James PACKE was born in 1726, he married his first wife Charlotte Pochin, and died in 1816. They had issue Rebecca (b. 1752), Charlotte (b. 1755), and Charles James, named after his father. The elder Charles James PACKE later married Catharine Cufton, they had issue Frances (b. 1775), Cathernine-Maria (b. 1776), Anne (b. 1778), Clifton (b. 1779, d. 1780), and Henry (b. 1786 d. 1859).

Generation 6 Charles James PAcke II was born on $29^{\text {th }}$ January 1758, he married Penelope Geast of the Dugdale family in 1791, and died in 1837. They had issue Charles William, George Hussey, Edmund (b. 1799), James (b. 1801), and Augustus (b. 1805).

Generation 7 Charles William PACKE was born on $23^{\text {th }}$ September 1792, he married Kitty Jenkyn REAding in November 1821, was elected as an MP in 1836, and died on $27^{\text {th }}$ October 1867. They did not have issue, and upon Charles William's death the estate was passed on to his younger brother George Hussey. George Hussey PACKE was born in 1796, he married Mary Anne Lydia HeAthCote in 1824, was elected as an MP in 1859, and died in 1874. They had issue Hussey.

Generation 7 Hussey PACKE was born on $7^{\text {th }}$ December 1846 , he married Alice WodeHouse, and died on $8^{\text {th }}$ October 1908. They had issue Edward Hussey.

Generation 8 Sir Edward Hussey PACKE was born on $6^{\text {th }}$ January 1878, he married Mary Sydney Colebrooke in 1909, and died on $11^{\text {th }}$ May 1946. They had issue Penelope Mary and Ursula Sybil (b. 1913 d. 1989). 
Generation 8 Penelope Mary PACKE married John Drury Boteler DruRY-Lowe in 1936. They created the Packe-Drury-Lowe family and had issue Simon Jasper.

Generation 9 Simon Jasper PACKE-DRURY-Lowe was born on $10^{\text {th }}$ February 1938, married Laura Julietta MADDOCKs-WRIGHT on $23^{\text {th }}$ June 1962 , and died on $15^{\text {th }}$ May 2015 . They had issue Edward.

Generation 10 Edward Packe-Drury-Lowe was born in May 1965, and is the current lord of Prestwold Manor.

Sources used: Sylvanus (1837, p. 656), Nichols (1800, p. 362), and Cross (1993, p. 21) 


\section{Aristocratic consumption}

This section will discuss the changes to Prestwold under Charles James Packe II. Charles James II made a series of changes to the estate, which this section will argue were driven by aesthetic or cultural choices. There was a running down of the estate and its finances, followed by physical changes to the estate, such as the movement of the road, and most importantly the removal of Prestwold village.

Most of the information for the condition of the estate comes from a personal record, written in 1860 by Charles William Packe (DE1346/468). The narrative details a long-running dispute between Charles William and his brother George Hussey Packe over the inheritance of the estate. In 1818, Charles James Packe II explained to his eldest son, Charles William, that he would leave a legacy of $£ 7,000$ each to three of his sons, while George Hussey would only receive a token sum of $£ 50$ as he had already settled on the Caythorpe Estate. In order to pay for this legacy to his sons, Charles James II encumbered the Prestwold Estate with a debt of $£ 17,000$ which he planned to pay off over the rest of his life. In 1835, he wrote a will which included $£ 25,000$ to be paid to his mother, and increased the amount bequeathed to each of his sons from $£ 7,000$ to $£ 20,000$. He also complained that his father had "not only not improved the property, but had suffered the buildings to go out of repair". Despite these complaints, Charles James II himself made no significant improvements to Prestwold Hall, although he did make extensive changes to the surrounding estate.

Upon the death of Charles James II in 1837, it was discovered that there was not enough money to pay the promised legacies. The $£ 17,000$ debt on the estate had not been paid off, and was actually accumulating interest of $£ 680$ per year. Charles William then found himself in a difficult situation, inheriting an indebted estate, and without the money to pay his brothers their promised legacies. The estate at this point was only generating a surplus of $£ 1,320$ per year, and the family narrative recounts that this was not enough money 
to "keep up a large Family Mansion, to provide for the annual outgoings on the estate, and to fulfil those expectations which [Charles William's] new position entailed upon him" (DE1346/468). As a result, Charles William reduced the legacy to be paid to his brothers, he also sold off the moiety ${ }^{2}$ of the Hale estate in Lincolnshire, which he had inherited from his aunt. A valuation of the estate was carried out on $20^{\text {th }}$ March 1837 (DE1346/460), shortly after Charles James II's death:

\begin{tabular}{lr} 
Description & Value in $£$ \\
\hline Household goods and furniture & 1,837 \\
Plate, linen, and china & 1,035 \\
Farming stock and implements & 960 \\
Wines and spirits & 760 \\
Books, prints and pictures & 560 \\
Horses, carriages, and saddlery & 240 \\
Garden frames, tools & 54 \\
Watches and ornaments & 30 \\
Apparel & 25 \\
\hline Total & 5,471
\end{tabular}

The figure for wine and spirits stands out as an unusually high proportion of the total value of the estate. If Charles James II was accused of gratuitous spending, the amount invested in wine gives a measure of that claim. We can compare it with the accounts of Charles James II's son, Edmund Packe (DE7430/2). These accounts show Edmund's yearly spend on grocery, coal, and wine (in pounds sterling):

\footnotetext{
${ }^{2}$ A moiety is a share in property, often passed on to women in case there was no male heir to inherit the whole property.
} 


\begin{tabular}{cccc} 
Year & Grocery & Coal & Wine \\
\hline 1834 & 11 & 20 & 134 \\
1835 & 24 & 24 & 4 \\
1836 & 29 & - & 69 \\
1837 & 14 & 22 & 118 \\
1838 & 21 & 41 & 68 \\
1839 & 12 & 35 & 15 \\
1840 & 18 & 29 & 20
\end{tabular}

In 1834, Edmund Packe's alcohol budget was ten times his food budget. Meanwhile, he spent almost nothing on wine in 1836, and this dissertation can not attribute the estate's overall financial problems to lavish spending on luxuries. However, these accounts do give us a picture of the Packe family's pattern of consumption at the time. That pattern is broadly representative of aristocratic excess, and it does not fit with the austere and prudent behaviour which emerges from capitalist rationalisation. It is also interesting to see that around this period, the rents of the estate remained stable. For example, a tenant called John Ashby consistently paid £375 per year in rent in Prestwold between 1832 and 1836 (DE1346/221). Despite the estate's financial troubles, it appears that no attempt was made to increase revenues by raising rents.

Charles William had the option of selling off the household goods to lift the estate's finances. He did not do this immediately, however the household goods were sold off while the estate was in his possession. There exists an undated sales catalogue which lists all his property in the hall, it contains 1,468 items and is dated for auction on $4^{\text {th }}$ October, but gives no year (DE1346/275). This could relate to the later period around 1853 when Charles William decided to leave Prestwold completely and move to Branksome in Dorset (Cross 1993, p. 10). The family narrative notes that he eventually "shut up the [Prestwold] mansion because he could not afford to keep two country houses" (DE1346/468). Altogether, the Prestwold estate was left in an uneasy financial situation by both Charles James I and Charles James II, and Charles William could not afford to keep the estate running. If Charles William took the decision to leave 
the house empty, it's because he considered it was too expensive to maintain, and overall the estate was not profitable enough to pay for its own upkeep. In this way Charles William was reacting to economic pressure. He did rebuild the house itself, and this will be explored in more detail in section 6 .

\subsection{Timber}

Charles James II had introduced a condition on the inheritance in 1821, that no trees on the estate were to be cut down without the permission of two men - Mr Phillips and Mr Pares. A further condition was that the sale of wood from the estate was limited to $£ 200$ annually (Shipley 2011, p. 128). This was a strict condition, it came with the threat of disinheriting Charles William if he refused to agree, and it shows how important the trees were to Charles James II.

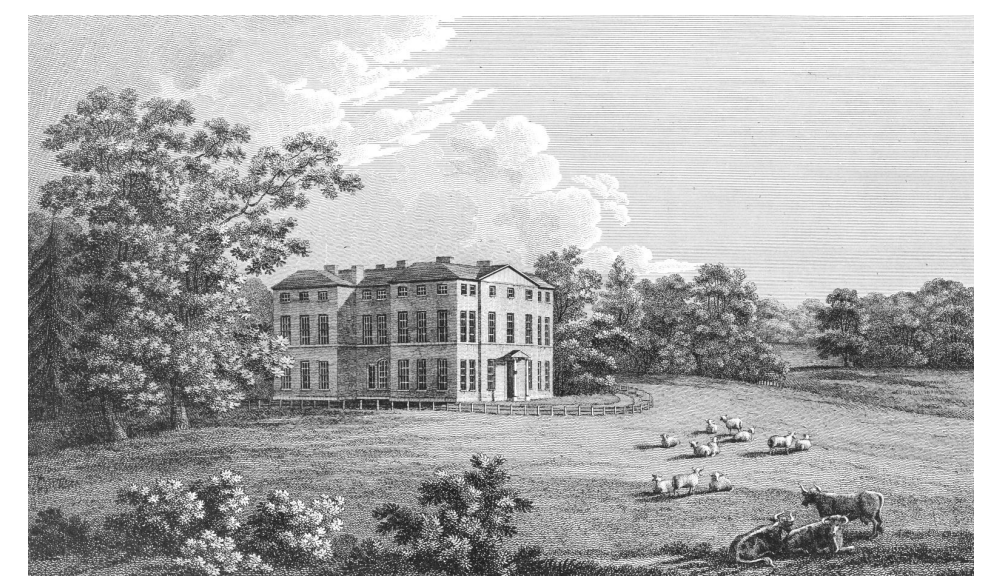

Figure 3: An engraving of Prestwold manor by James Bafire. Printed in Nichols (1800, pp. 355-356).

The wood is mentioned several times in descriptions of the estate. An obituary of Charles William refers to the village of Prestwold as having been "auburnised" (DE1346/471). This was after the village had been removed and the forest planted over it. The term 
"auburnised" might refer to the fictional Irish village of Auburn the subject of a poem called the Deserted Village by Oliver Goldsmith. Alternatively, it could simply refer to the auburn colour of the trees around Prestwold. The imagery of the abundant natural forest landscape had a particular importance for representations of the landscape at the time (Elliott et al. 2011, pp. 25,35). For example, Patrick Abercrombie described in colourful language the capitalist landowner as a 'land butcher' - "a personage entirely ruthless and untrammelled by traditions" ... who develops the land "in the most brutal manner" (Abercrombie 1930, p. 214; cited in Matless 2016, p. 50). Abercrombie is particularly concerned about the destruction of trees, which he sees as the targets of landowners seeking to extract revenue from unprofitable estates (Abercrombie 1930, p. 215). Another description of the estate in 1800 refers repeatedly to the trees and wooded areas:

This house is large, commodious, and neat. . . bosomed in calm serenity, and, as a near object, has many pleasing attractions. The grounds before it are spacious, and possess much of a park-like appearance; and the house, in every point of view, shews itself delightfully shaded with wood, being ornamented with large plantations of forest trees; Mr. Packe having, perhaps, planted and raised, within the last 30 years, more trees than any gentleman in this country. The land is good, and their progress is very great; being at present very beautiful, and many of them fit to cut for various purposes; and to the next generation they will be highly productive... not a hedge, nor even a gravel-pit, is there to be seen, but what is planted with ash, oak, or elm. (Nichols 1800, p. 355; cited in "Prestwold in 1800" 1995, p. 8)

The reference to Prestwold having a "park-like appearance... shaded with wood" is also made by Throsby (1789, p. 306). Later in 1821, another description mentions that Prestwold Hall "has the effect of being embosomed in one entire wood," and that 
the estate contains "the finest growing timber" (DE3969/38/1). It's possible that Charles James II recognised the financial value of the timber, as a material resource which could be felled in order to prop up the estate's finances. This brings up a contradiction, between on the one hand the demand to realise the value of the wood by razing the forest and selling the timber, and on the other hand the maintenance of the forest as a distinguishing feature of the estate's natural landscape.

According to Charles William's own account, he did not break his father's conditions on cutting wood (DE1346/468). However in the legal case after his death, he was accused of selling £5,248 worth of timber between 1837 and 1861 ("Packe v Packe-Reading" 1870). Without the ability to judge whether or not Charles William was really guilty of this, it is true that in the present day the estate is still surrounded by dense patches of woodland. When cycling along the southern and western contours of the estate on Loughborough Road and Prestwold Lane, the manor house is noticeably obscured by the tree line. The trees act as a natural barrier, both to physically mark the edge of the estate, as well as to keep the view of the house private. Privacy became an important feature of country estates at the time; as the architects and estate planners continued to bring forth idyllic surroundings, this was matched by an effort to make sure the new landscapes were to be enjoyed exclusively by the owners of the manor (Daniels and Seymour 1990, pp. 503-504). As another example, in 1842 William Burn planned

a ha-ha wall, which would have had the effect of further fortifying the grounds while preserving the view from the house (Prestwold Hall listing 1986).

\subsection{Displacement of Prestwold village}

One of the main changes brought about by Charles James II was the displacement of the village of Prestwold. The village is visible on early maps of Leicestershire before the early 1800s. 


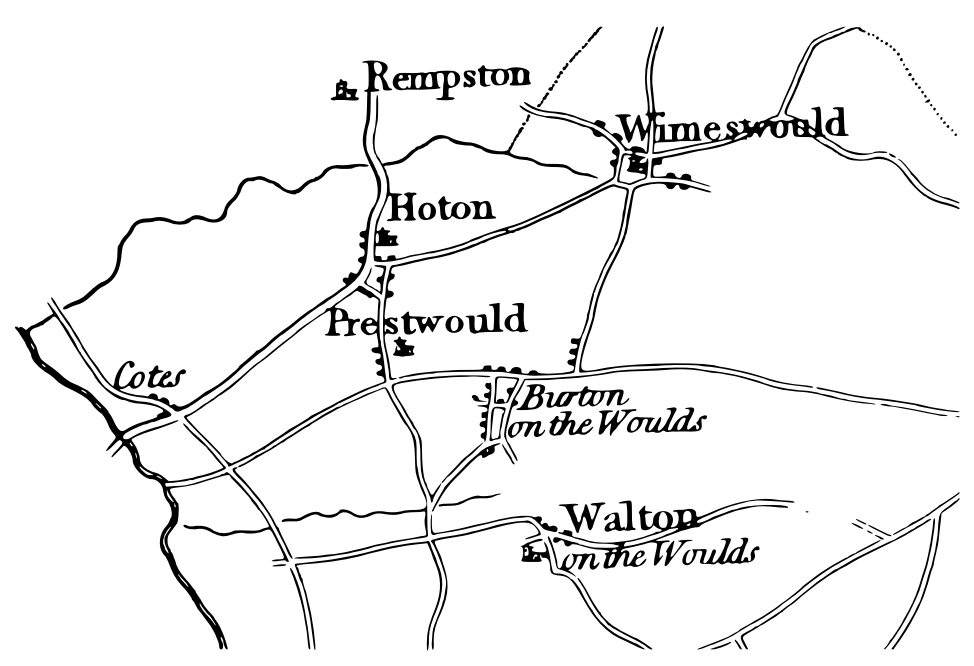

Figure 4: Prestwold village shown in a map of East Goscote hundred by J Cary. Printed in Nichols (1800, pp. 2-3)

In figure 4, the map shows a few houses, as well as St. Andrew's Church, which remained in place after the village was gone. The Historic England listing for Prestwold Hall mentions that, in the $18^{\text {th }}$ Century, the village would have been made up of only around a halfdozen farms. The listing does claim that the village may have been much larger in earlier periods, although this is difficult to measure without looking into archaeological evidence (Prestwold Hall listing 1986). Apart from the manor house and the church, the only other surviving structure from the old village is a $16^{\text {th }}$ Century building called Laundry Cottage (ibid.).

In figure 5, the map shows a track leading off Prestwold Lane, this follows the approximate line of what is currently the long driveway leading to the manor house, and Hussey (1959a) suggests that the village would have extended along that driveway. The map also features a building next to the church, and this would have been the village pub (Shaw et al. 2000, pp. 6-8). An earlier estate survey was made in 1735, and this is referenced by the Historic England listing. The original survey is kept by the Leicester Record Office, and there are two photographs of it available at the record M418/12. The 1735 survey shows more buildings clustered around the 


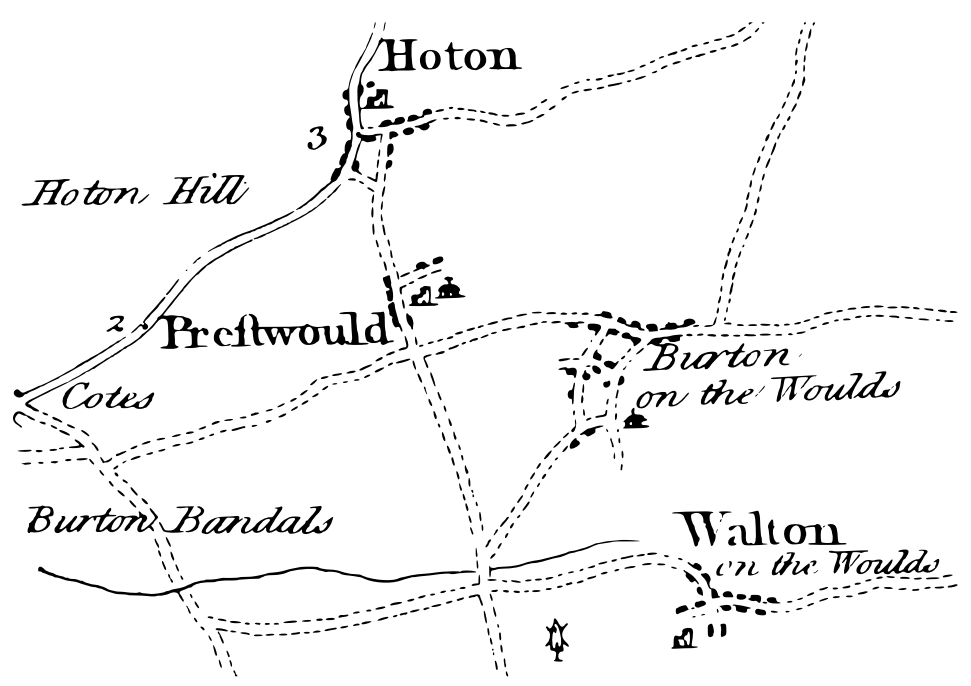

Figure 5: Prestwold village shown in John Prior's map of Leicestershire, 1777. Reproduced in Prior (1984, p. 24) and Shaw et al. (2000, p. 9).

crossroads, as well as a straight tree-lined road leading straight from Cotes to Prestwold. The road in the survey doesn't line up with the current Loughborough Road, and satellite imagery does not show any obvious traces of a straight road, so it's possible it was a planned development which never came to fruition.

When Prestwold village was removed, most of the villagers were displaced to nearby Hoton. Hoton had been enclosed by act of parliament in 1760 (Trushaw 2005, p. 25), and was annexed by the Prestwold estate in 1821. Prestwold contained a village school, which was located near the Manor House, and classes may have been held in St. Andrew's Church. This school was also moved to a new building on the junction between Nottingham Road, Prestwold Lane, and Loughborough Road (DE1749/87/2), although it is unclear whether it was Charles James II or his son who supported the construction of the school. 


\subsection{Movement of the road}

As part of the changes to the estate, the road from Burton through to Leicester was diverted to make way for a southwards expansion of the hall grounds (Shaw et al. 2000). At the time, the entrance to the hall faced south. The maps in figures 5 and 4 show crossroads; where what is now Barrow Road would have continued on after crossing Prestwold Lane. The continuation of this road would likely have followed the line of the stream cutting across the estate, passing by the manor house. There are old houses in Burton on the edge of this stream, where it would have connected to the road. The diversion gives more space around the estate, at the expense of a less direct route between Burton and Barrow Road. 


\section{Entrepreneurial gentrification}

This section will look at the life of Charles William Packe, son of Charles James Packe II, and compare how they both sought to manage the Prestwold estate. This section is concerned with the question of the embourgeoisement or gentrification of the aristocracy. How do entrepreneurial and aristocratic approaches compare, where do they diverge, and to what extent are they compatible? This section will read the encroachment of entrepreneurial values as both a proponent and a consequence of gentrification.

Section 5 shows that the tenure of Charles James II at Prestwold was characterised by consumption, and business decisions which left the estate in a precarious financial situation (Shipley 2011, pp. 127-128). This can be counterposed with his son Charles William, who seems to have been concerned with resolving the estate's finances before deciding to leave the estate altogether in the 1850s. ${ }^{3}$ In this reading of the history, Charles William represents the changing values of the aristocracy, with a focus on advancing a capitalist class interest, rather than building on power invested in the family.

Charles William's decision to vacate his family seat in Prestwold and move to Dorset can be seen as the culmination of a personal dispute between himself, his late father, and his brother George Hussey. However, as discussed in section 5, that dispute was framed by the estate's financial situation, and the result wasn't limited to a family quarrel. When Charles William left Prestwold, he cut the connection between the Prestwold estate and the Packe family. Going back to around $1760,{ }^{4}$ the Packe family had kept up continuous residence in the ancestral mansion, and it's significant

\footnotetext{
${ }^{3}$ Charles William bought land in Branksome in 1853, and completely ceased residing in Prestwold in October 1858 ("Packe v Packe-Reading" 1870), so the move occurred between that period.

${ }^{4}$ This is the year that Prestwold hall was first rebuilt in a Georgian style and the parks laid out. It is also the same year that Hoton was enclosed. Before this time the main family hall would have been in Cotes.
} 
that Charles William was the first to break from that tradition. Furthermore, he had requested that he not be interned in the family mausoleum on his death, instead he was laid to rest in a separate mausoleum in Branksome.

Charles William did not have children, and again he was the first since Charles Packe to not directly propagate the family line. The research for this dissertation did not uncover why he failed to produce an heir, whether it was due to a medical condition, or due to a genuine lack of dynastic ambition. Whatever the reason, his actions demonstrated a level of autonomy which was not shown by his forefathers. His position as an MP may have helped in this, by affording him a status which was not immediately conditional on the family or the estate. He had been first elected as an MP for Leicestershire South Division in 1836, after his predecessor Thomas Turner resigned in February of that year (H. S. Smith 1844, p. 192). He stood as a Tory, and was re-elected along with another Tory MP for South Leicestershire the following year in 1837. He was re-elected in 1841 in a contest against two Liberal candidates. This was the one and only time his South Leicestershire seat was challenged, as he was re-elected unopposed in subsequent elections in 1847, 1852, 1857, 1859 and 1865 (Craig 1977, p. 417). He held the seat continuously for 31 years until his death, although his attendance record in parliament dwindled into the 1860 s. The fact that he was elected unopposed so many times is not unusual, however it does suggest that his seat in parliament might have been determined by patrimonial influence, rather than open political contest. It also fits an organic connection between land-ownership and representation in parliament (Swade et al. 2019, p. 28).

\subsection{Building renovation}

Although Charles William refers to the upkeep of Prestwold as 'unaffordable' (DE 1346/468), there are other reasons to believe he was not exclusively motivated by the single desire to save money on an expensive house. His move to Dorset was preceded in 1842 by a two- 
year project to remodel Prestwold Hall. Charles William employed a Scottish architect called William Burn to redesign the building in an Italian style. As part of this redesign the entrance was moved to face south into the forest, and the entrance itself was extended into a porch and large entrance hall. The lawn to the west was dug up and replaced with a classical garden. The building overall was enlarged, with a conservatory looking out over the new garden. Thick stone walls were replaced with large windows, which let in sunlight and made the landscape more visible from inside. The interior living spaces were redecorated too, the ceiling of the entrance hall was painted with patterns inspired by the work of Raphael in the Vatican (Hussey 1959b); decorative coves and archways were added to the corridors (Girouard 1979, pp. 140-143). A new service wing was also built, extending northwards from the back. This contained, among other facilities, a washing house, a dairy, coal store, bake house, laundry, large kitchen, multiple pantries, larders, sculleries, a servants hall and a brew house (ibid., p. 142).

The new service wing gives a clue as to why the house might have been more difficult to afford. All the new rooms for washing, cleaning, brewing, and cooking, would have been staffed by a workforce of washers, cooks, cleaners and servants. An expansion of the service staff, with all their attendant demands for housing and salaries, would have represented an ongoing cost to maintenance of the house. Also, during the three decades after Charles William decides to leave Prestwold, the population of the parish drops considerably. From a population of 965 recorded in the 1851 census, to only 83 persons recorded in the 1881 census. ${ }^{5}$ The total disappearance of around 880 people from the parish could not be attributed exclusively to Charles William's actions, and could be part of a general trend towards urbanisation. For comparison, the population of Loughborough expanded by 3,567 between 1871 and 1881 censuses, and this loosely coincides with the beginning of steam locomotive production at the Falcon Works site.

\footnotetext{
${ }^{5}$ The census records are reproduced in appendix B
} 
Figure 6: Annual expenditure on luxury items by the Packe family

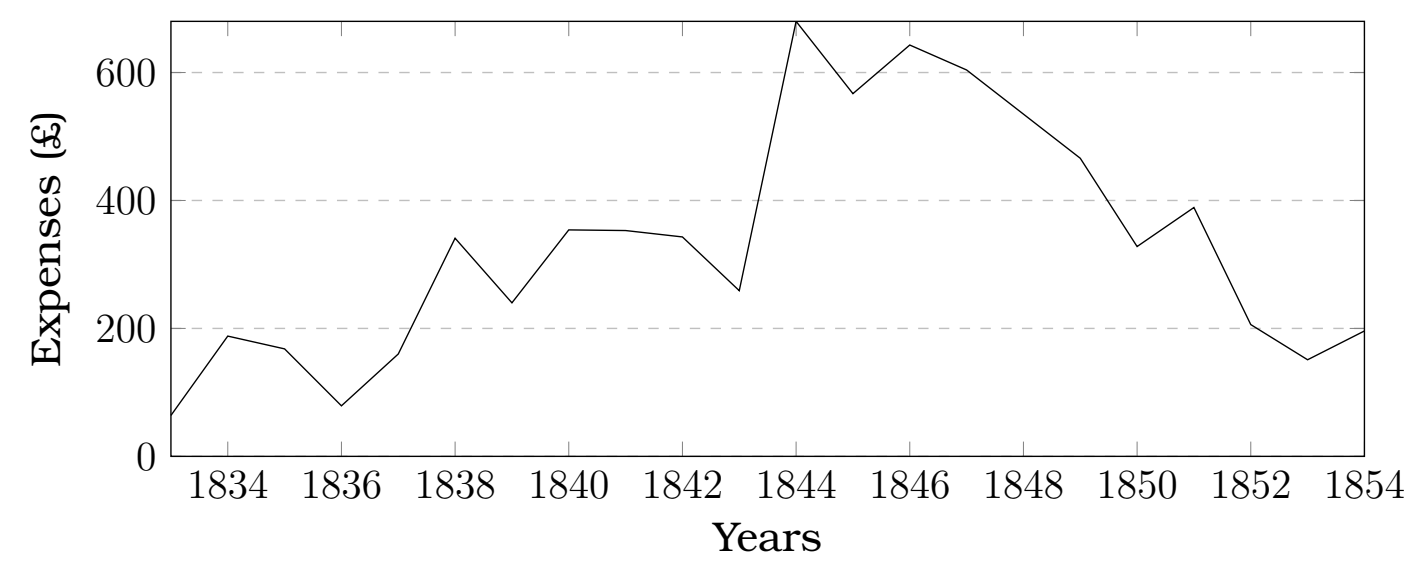

The family accounts track overall expenditure on books, wine, linen, furniture, plate, horses and works of art.(DE1346/350) A graph of this expenditure is shown in figure 6 , with the original accounts table available in appendix A. As shown in figure 6, the amount spent on the estate rose sharply around 1844-1847. This coincides with the period after the renovations on the hall were finished, and it drops off towards the 1850s. As this category includes art and furniture, the increase in expenditure around 1844 could be attributed to the upfront cost of furnishing the house. Once the house was fully decorated with artworks and furniture, he had no need to keep spending, and the expenditure gradually came down.

Alongside these expenses, the accounts show the family operated a separate public amusement fund from 1844-1851, which mainly involved paying for an opera box (DE1346/350). This is notable because it shows that the Charles William was not only willing to spend money on cultural pursuits, but also that he was obligated to keep up regular entertainments. Charles William's personal statement refers to the burden on him to "provide for the annual outgoings on the estate, and to fulfil those expectations which his new position entailed upon him" (DE1346/468). His social position was renewed and reinforced through social engagements, which in turn entailed visibly spending money on parties, opera, 
and other public amusements. At some point, Charles William decided that this particular lifestyle was too costly to support.

\subsection{Rationalised architecture}

While the renovation of Prestwold Hall didn't show any immediate monetary return, Charles William did not approach the project with a mind to gratuitous spending. In a description of Burn's work, Mark Girouard (1979, p. 138) refers to Charles William as "cautious with his money" and suggests that Burn was appreciated for his ability to make the most of a limited budget. As an architect, Burn was reluctant to work on projects with too much of what he considered as 'unnecessary expense' (Walker 1976, p. 10). The results of the low-cost renovation can be seen in the final construction. For example, the conservatory was constructed with brick, rather than large slabs of stone (Hussey 1959a), and this was a way of saving money on materials.

Charles William was clearly able to pay for work to bring the house up to date with the latest fashions, but he didn't want to spend excessively. After his death, Burn was called in to design the mausoleum. In keeping with Burn's reputation as a cost-effective architect, he argued over the wages of the builders and reworked the design to keep it under a $£ 1,000^{6}$ budget (Cross 1993, pp. 1718). Also in relation to the mausoleum, Charles William's wife Kitty Jenkyn was unusually concerned about the cost of her funeral. Her will stated that if she were to die away from her residence in Branksome, that her coffin should be placed in a plain box and sent on a standard goods train to Branksome Tower for burial (Bullock 1878, pp. 126-127). The couple displayed a thriftiness and an awareness of financial constraints which characterises them as part of the landed gentry which was coming to terms with the market competition. They were compelled to keep up with the intensification of capital accumulation, and this behaviour of financial restraint can

\footnotetext{
${ }^{6}$ The budget of £1,000 was set out in Charles William Packe's will of 1866.
} 
be read as a consequence of that. In historical periods of capitalist advance, the impetus to accumulate coincided with a cultural drive to promote values of austerity and thriftiness (Sombart 1930, pp. 105-109; Chriss 2019, p. 53).

The renovation of Prestwold Hall can be understood as a calculation of different forces. The importance of the building for upholding Charles William's social position, balanced against the cost of the construction work, the ongoing cost of maintenance and service staff, and the potential to capture future value by selling or renting out the house.

\subsection{Improvement as ideology}

Charles William's preference for economy also sits within a narrative of agricultural improvement. In terms of his relations with the land, a newspaper report described Charles William as taking

a deep interest in everything connected with agriculture. He was a considerable occupier, and bestowed much attention to good husbandry, the breeding of cattle, the improvement of farm labourers, and to every subject related to the land (DE1346/471).

Whether or not this description of Charles William is accurate, it nonetheless tells us about how landowners were represented. Charles William played the role of a responsible landowner, someone with an interest in improving the land. This improvement can take the form of simply bringing the landscape in line with contemporary fashions, although it's often connected to productivity. When Charles William is said to pay attention to good husbandry, this returns to the impetus to reinvest and grow capital. Healthy, well-fed animals are a sign of wealth, they represent a socially respectable form of "added value" (Daugstad et al. 2006, pp. 70-72). 
as well as providing revenue. The same newspaper report mentions that Charles William served as the president of the Loughborough Agricultural Society (T. Thompson 1839, DE1346/471). A portrait of him shows him holding a book, with a sketch of a country house on the table to his side.

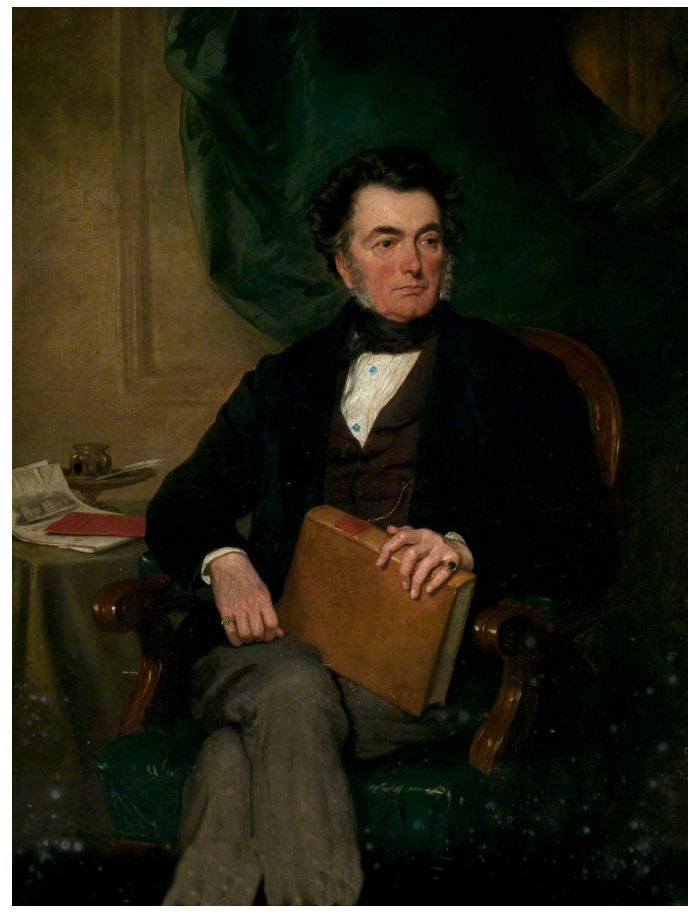

Figure 7: An undated painting of Charles William Packe held at the New Walk Art Museum. Picture reproduced under the terms of the Creative Commons BY-NC-SA license.

The family accounts also show that from 1835 onward the family maintained a subscription to Mechanics Magazine (DE1346/350). The magazine covered the innovations in machinery and technology which were being produced through the Industrial Revolution. So, these actions come together to present an image of a man who keeps up with the latest inventions, who reads, and who is a patron of scientific advance. It may not be an objectively accurate description of his character, although it does reflect the rational enlightenment values he sought to embody. 


\subsection{Development around Prestwold}

While Charles William was at Prestwold, he made various attempts to make up for his father's displacement of the original village. New cottages were built in Hoton, as well as a line of 8 buildings around 400 metres north up Loughborough Road from the original village. These buildings comprise the current settlement of Prestwold. Several other estates in Leicestershire were also engaged in building cottages around this period, and there was a fashion for designing 'ideal' or model homes for workers (Ayres 2004, pp. 124126). Charles William also paid for the rebuilding of Hoton church, which had fallen into disrepair, and he may have helped build the new school house on the junction of Loughborough Road, Prestwold Lane, and Nottingham Road (Cross 1993, pp. 7-8). In addition to this, Charles William operated a small savings bank for the villagers on his land (DE1749/87/2). He would make contributions of two florins to accounts which held a large balance for a long time. The exact conditions for his contribution were left unspecified, and so his payment into the villagers' accounts was as much an act of charity as it was an inducement for them to use the bank. Meanwhile, though it might have been presented as a charitable exercise, the deposits must have been a useful way of raising capital. It was also an extension of entrepreneurial attitudes from the gentry down to the workers, seeking to instil the workforce with a sense of personal responsibility and self-reliance. With the effect of suppressing notions of communal responsibility and solidarity between workers. Charles William's allegedly benevolent actions fit uneasily with a characterisation of the 'new' gentry as a disruptive force, set against 'old' landowners who were thought to be bound by paternalistic traditions. The improvements he makes always reveal a class interest: to produce a modern proletariat which is sober, healthy, hard-working, and above all loyal to him personally. 


\subsection{Branksome Tower}

Charles William bought 735 acres of land as part of the Branksome estate in 1853, and he paid $£ 12,000$ - a price which the surveyor assessed as being above market value (Cross 1993, p. 10). The purchase of the land was part-funded by a $£ 7,000$ loan, and the rest made up from Charles William's savings. It is curious that he was able to find the money to buy another estate, and it raises a question about the source of his income. Shipley (2011, p. 122) suggests that Charles William held 'bank stocks, government consols, and railway shares' - and also that by the time he died he was making £4,267 in rental income from his land in Leicestershire. William Burn was again employed to build the new Branksome Tower mansion.

The surveyor, a local figure called Christopher Crabb Creeke, noted that the estate was valued more in its capacity a leisure retreat than as agricultural land, nevertheless Charles William did attempt to exploit it. There were reserves of clay on the estate, and so he set up a brick-making operation. Unfortunately, he could not find enough good quality clay and the pottery turned out to be unprofitable. He considered cutting the trees on the estate, however the dominant variety of trees were pineaster firs, and these did not fetch a high enough price to make it worthwhile razing the estate (Cross 1993, pp. 11-12).

Bournemouth and its surroundings were growing in popularity as a seaside resort, and the construction of Branksome Tower was described as "the core of Poole's transformation from hamlet to watering hole to upmarket suburb" (Cocke 2006, p. 6). Charles William also supported the construction of the Bournemouth Sanatorium, and he was present at the ceremonial opening of the pier (Cross 1993, pp. 13,15). Christopher Creeke seems to have played the role of a fixer in attracting gentlemen to invest in recreational infrastructure around the nascent town.

Overall, the renovation of Prestwold, its subsequent abandonment and the move to Branksome, these come together as a se- 
quence of wasteful decisions. Charles William sank money into rebuilding one mansion, before moving on to build a second one, neither of his schemes turned out particularly successful, and at the end he didn't leave much behind for his family. For example, when Charles William left Prestwold, he arranged for some of his renovations to be dismantled - he removed the marble from the entrance hall, the roof of the conservatory, and other valuable metal parts of the building. These were moved to Dorset and added to Branksome Tower. Meanwhile, Prestwold Hall was left empty and the building steadily degenerated. Prestwold hall was visited by Hussey Packe in November 1867, one month after the death of Charles William. Birds and bats were nesting in the garret, there were weeds growing inside the house, and some wooden beams were rotten ("Packe $\mathrm{v}$ Packe-Reading" 1870, p. 6). Branksome Tower did not remain in the Packe family: after the death of Charles William's wife Kitty, their land was broken up and sold off in parcels, ${ }^{7}$ the mansion house itself was also sold and turned into a hotel. While it was operating, the Branksome Tower hotel continued to make use of the Packe family coat of arms for its logo.

7 A plan of the Branksome estate from 1883 shows the parcels of land sold and marked for future sale https://www.flickr.com/photos/alwyn_ladell/ $5909587343 /$ 


\section{Conclusion}

The original capture of the Prestwold estate by the Packe family was framed by rising merchant interests, backed by the force of the state. However, from the very beginning, Christopher Packe chose to integrate himself into the aristocracy rather than overturn existing power relations. He became titled and formed a new dynasty whose origins did not lie in the Norman Conquest; his land and the rights associated with it were acquired through a semi-legal process. He grew his wealth first by taxing the physical transport of cotton, and then through the financial transfer of money in and out of state coffers. As such he accumulated capital through formally economic rather than extra-economic extraction. In this way, he became one of the early members of the landed gentry, both capitalist and aristocratic.

Charles Packe II exemplified a pattern of aristocratic consumption. He was disinterested in seeking profitable ventures and overpromised his inheritance, and left the estate with debt. Meanwhile, he also gentrified Prestwold, he cleared the villagers away from around the hall, expanded the lawn southwards and diverted the road. This displacement transformed the grounds, from a living village with a church and a pub, to the landscape depicted in figure 3 - a flat lawn containing a few cows and sheep, but no people.

Charles William Packe played the role of a capitalist landowner, he repeatedly sought out opportunities for exploitation, yet none of his attempts were successful. He embarked on a career in parliament, not as a member of the House of Lords but in the Commons as a Tory MP. In his move to Branksome, he became an early agent of gentrification in Bournemouth, and he participated in the creation of the town as a leisure resort, leaving behind a house which was eventually turned into a seaside hotel.

In all three cases, the Packes of Prestwold were the leading protagonists of displacement. First, by replacing the Skipwith family, which triggered their move out to the American colonies. Then, re- 
moving the old villagers of Prestwold through repeated renovations of the estate. Finally by shutting down Prestwold itself, and moving out to Bournemouth to reserve a section of the coast for exclusive use as a seaside retreat.

The final point to raise from this study is how stable and consistent the Packe lineage remained throughout all the changes. Of all the grand families in Leicester, many of them went through periods of financial hardship, but very rarely did they lose control of their estates (Shipley 2011, pp. 128-129). An understanding of capitalist transformation in Britain has to take into account this unbroken continuity, and what it means for the nature of capitalist power. The old elites were not overthrown, they adapted, and they still hold onto their ancient fiefdoms. Even today, their position remains largely unshaken, Prestwold is still the seat of the Packe family (now merged as Packe-Drury-Lowe). In the USA, the presidency is held by a prominent landowner, and this trend goes all the way back to George Washington (Stein 2019, Chapter 4; Huron 2019). In Britain, is remarkable to think that Sir Christopher Packe and Sir Athur Haselrig sat together in parliament as Leicester MPs, and over three centuries later their direct descendants were personal friends at Eton (DE3969/51 Packe 1976, p. 17). What stands out is not what has changed, but what has stayed constant. 


\section{Archival sources}

This dissertation makes use of records from the Leicestershire Local Records Office. The reference codes and their descriptions are listed below.

DE3969/51 Draft copy of Our Founding Ancestor.

DE6289 Wolds life project records.

DE3969/17 Notes on Christopher Packe, 1593-1682.

DE 1346/468 Personal statement of Charles William Packe, 1860.

DE1346/460 Valuation of the effects of the late CJ Packe.

DE7430/2 Account book \& memoir of Edmund Packe, 1799-1874.

DE1346/221 Tenant book for the Prestwold Estate, 1818-1848.

DE1346/275 Catalogue of furniture in Prestwold Hall.

DE 1346/471 Newspaper clippings from Packe obituary, no date.

DE3969/38/1-2 Description of Prestwold Hall, seat of Charles James Packe esq. 1821.

M418/1-2 Photographs of the 1735 Prestwold estate survey.

DE1749/87/2 Report on the Prestwold settled estates, 1867.

DE1346/350 Prestwold estate accounts book, 1833-56.

\section{Bibliography}

Abercrombie, Patrick. "The English Countryside". In: The Political Quarterly 1.2 (1930), pp. 207-225. ISsN: 1467-923X. DOI: $10.1111 / \mathrm{j} .1467$ 923X.1930.tb01480.x.

Ayres, Martin. "The provision of housing and power relations in rural England, 1834-1914". PhD thesis. University of Leicester, Sept. 2004. $241 \mathrm{pp}$. 
Bartley, Tim. "Toward a Political Sociology of Land". In: The Politics of Land. Vol. 26. Research in Political Sociology. Feb. 25, 2019, pp. 1-12. Dor: 10.1108/S0895-993520190000026005.

Bastani, Aaron. Technology and Post Capitalism. In collab. with David Harvey, Paul Mason, Alice Bell, and James Meadway. Panel discussion at The World Transformed. Sept. 25, 2017.

Bibby, Peter and Paul Brindley. Urban and Rural Area Definitions for Policy Purposes in England and Wales: Methodology. Office for National Statistics, Aug. 28, 2013, p. 36.

Bibby, Peter and John Shepherd. Developing a New Classification of Urban and Rural Areas for Policy Purposes. July 29, 2005, p. 30.

Borras, Saturnino M. "Agrarian Social Movements: the absurdly difficult but not impossible agenda of defeating right-wing populism and exploring a socialist future”. In: Journal of Agrarian Change (Mar. 2019). ISSN: 1471-0366. DoI: 10.1111/joac.12311.

Bullock, Charles. Many Things. London: Hand and Heart, 1878. 206 pp.

Butlin, Robin A. The Transformation of Rural England, c. 1580-1800: A study in historical geography. Shelfmark 910.942 BUT. Oxford University Press, 1982. ISBN: 978-0-19-874046-9.

Castree, Noel, Neil M Coe, Kevin Ward, and Michael Samers. Spaces of Work: global capitalism and geographies of labour. Social Science Library shelfmark HD4851 SPA. London: SAGE, 2004. 303 pp. ISBN: 978-0-7619-7216-7.

Chriss, James J. "Weber's Protestant Ethic Thesis in Five Steps". In: Academicus 20 (2019), pp. 51-65. ISSN: 2079-3715. DOI: 10.7336/academicus . 2019.20.04.

Cocke, Thomas. "Visit to Dorset”. In: MMT News 16 (June 2006). Mausolea and Monuments Trust. IssN: 2056-6492.

Craig, FWS. British Parliamentary Election Results 1832-1885. London: Macmillan, 1977. 692 pp. IsBN: 978-1-349-02349-3.

Cromartie, John and Shawn Bucholtz. "Defining the "Rural" in Rural America”. In: Amber Waves (June 2008).

Cross, Joy. Prestwold Hall to Branksome Tower. Bournemouth Local Studies Publications, 1993. IsBN: 0-906287-97-9.

Daniels, Stephen. Fields of Vision: Landscape Imagery and National Identity in England and the United States. Princeton University Press, Jan. 1993. 274 pp. ISBN: 978-0-691-03273-3.

Daniels, Stephen and Suzanne Seymour. "Landscape Design and the Idea of Improvement 1730-1900”. In: Historical Geography of England and Wales. Ed. by Robert A Dodgshon and Robin A Butlin. London: Aca- 
demic Press, 1990, pp. 487-520. ISBN: 978-0-12-219253-1. DOI: 10 . 1016/B978-0-12-219253-1.50024-5.

Daugstad, Karoline, Katrina Rønningen, and Birgitte Skar. "Agriculture as an upholder of cultural heritage? Conceptualizations and value judgements - a Norwegian perspective in international context”. In: Journal of Rural Studies 22.1 (Jan. 1, 2006), pp. 67-81. ISsN: 0743-0167. Dor: 10.1016/j.jrurstud.2005.06.002.

Dunford, Michael and Diane Perrons. The Arena of Capital. Critical Human Geography. Shelfmark D42.04 DUN. London: Macmillan, 1983. ISBN: 978-0-333-28263-2.

Elliott, Paul A, Charles Watkins, and Stephen Daniels. The British Arboretum: Trees, Science and Culture in the Nineteenth Century. Vol. 14. University of Pittsburgh Press, Mar. 1, 2011. 313 pp. ISBN: 978-0-82298167-1.

Esposito, Christopher. "The Role of Natural Amenities in Gentrification". PhD thesis. New York: Colgate University, 2014. 32 pp.

Everitt, Alan. "Town and Country in Victorian Leicestershire: The Role of the Village Carrier". In: Perspectives in English Urban History. Problems in Focus Series. London: Palgrave Macmillan, 1973, pp. 213-240. ISBN: 978-1-349-00575-8. Dor: 10.1007/978-1-349-00575-8_9.

Farnham, George F. "Prestwold and its Hamlets in Medieval Times". In: Transactions of the Leicestershire Archaeological and Historical Society 17.1 (1931), pp. 1-84.

Gale, Dennis E. "A Moving Target: The Shifting Genealogy of Gentrification”. In: The Routledge Handbook of Housing Policy and Planning. Ed. by Katrin B Anacker, Mai Thi Nguyen, and David P Varady. Routledge, July 2, 2019. IsBN: 978-1-317-28269-3.

Gavroche, Julius. Gentrification: The city as a field of appropriation, dislocation and segregation. Autonomies. May 27, 2015.

Girouard, Mark. The Victorian Country House. Shelfmark 720.942 GIR. Yale University Press, 1979. 467 pp. IsBN: 0-300-03472-5.

Glass, Ruth. "Introduction". In: London: Aspects of Change. Centre for Urban Studies report 3. Social Science Library shelfmark HT133. MacGibbon \& Kee, 1964, pp. xiii-xlii.

Gonen, Amiram. "Non inner-city gentrification in Israel". In: Dela 21 (Dec. 2004), pp. 437-444. ISsN: 1854-1089. Dor: 10.4312/dela.21.437-444.

Grey, Robin et al. Land for the Many: Changing the way our fundamental asset is used, owned and governed. Labour Party, June 2019, p. 75. 
Guelke, Leonard. Historical Understanding in Geography: An idealist approach. Cambridge Studies in Historical Geography 3. Shelfmark 910.9 GUE. Cambridge University Press, 1982. ISBN: 978-0-521-24678-1.

Harvey, David. “A Tale of Three Cities”. In: Tribune 2 (Oct. 1, 2019), pp. 5556. ISSN: 0041-2821.

- "Labor, Capital, and Class Struggle around the Built Environment in Advanced Capitalist Societies". In: Politics \& Society 6.3 (Sept. 1, 1976), pp. 265-295. ISSN: 0032-3292. DOI: 10.1177/003232927600600301.

- Rebel Cities: From the Right to the City to the Urban Revolution. London: Verso, Apr. 9, 2013. 208 pp. IsBN: 978-1-78168-074-2.

- The Geopolitics of Capitalism, Part 2. Anti-Capitalist Chronicles. Feb. 28, 2019.

- The New Imperialism. Shelfmark 327.73 HAR. Oxford University Press, 2005. ISBN: 978-0-19-927808-4.

- "The Right to the City". In: New Left Review 53 (Oct. 2008), pp. 23-40. ISSN: 0028-6060.

Heley, Jesse. "The new squirearchy and emergent cultures of the new middle classes in rural areas". In: Journal of Rural Studies 26.4 (Oct. 1, 2010), pp. 321-331. ISSN: 0743-0167. DOI: 10.1016/j . jrurstud. 2010. 03.002.

Herod, Andrew. "Local Political Practice in Response to a Manufacturing Plant Closure: How Geography Complicates Class Analysis”. In: Antipode 23.4 (1991), pp. 385-402. ISsN: 1467-8330. DoI: $10.1111 / \mathrm{j}$. 1467-8330.1991.tb00420.x.

- "Spatial Fix". In: Encyclopedia of Urban and Regional Studies. Wiley Blackwell, Apr. 15, 2019. ISBN: 978-1-118-56844-6.

- "Workers, Space, and Labor Geography". In: International Labor and Working-Class History 64 (2003), pp. 112-138. IssN: 0147-5479.

Hill, Christopher. Reformation to Industrial Revolution. Vol. 2. Pelican Economic History of Britain. Shelfmark D42 PEL. Penguin Books, 1969. 306 pp. ISBN: 0-14-020897-6.

Hobsbawm, Eric J. Industry and Empire: from 1750 to the present day. Shelfmark D42 HOB. Harmondsworth: Penguin, 1969. ISBN: 978-014-020898-6.

Hsu, Chia-Sui. "Rural Gentrification in Desakota: Farmland Politics, Alternative Food Networks, and the Emergence of New Farmers in Taiwan". PhD thesis. Lund University, Apr. 8, 2019.

Huron, Amanda. Capital City and the Nation's Capital. Society \& Space. May 2019. 
Hussey, Christopher. "Prestwold Hall, Leicestershire - I". In: Country Life 125.3248 (Apr. 16, 1959). Shelfmark PER 942 C8298. ISsN: 0045-8856.

- "Prestwold Hall, Leicestershire - II". In: Country Life 125.3249 (Apr. 23, 1959). Shelfmark PER 942 C8298. ISsN: 0045-8856.

— "Prestwold Hall, Leicestershire - III". In: Country Life 125.3250 (Apr. 30, 1959). Shelfmark PER 942 C8298. ISsN: 0045-8856.

Inwood, Shoshanah M. and Jill K. Clark. "Farm Adaptation at the RuralUrban Interface". In: Journal of Agriculture, Food Systems, and Community Development 4 (Dec. 11, 2013), pp. 61-78. ISSN: 2152-0801. DoI: 10.5304/jafscd.2013.041.007.

Jones, Peter, David Hillier, and Daphne Comfort. "Solar farm development in the United Kingdom”. In: Property Management (Apr. 14, 2014). ISsN: 0263-7472. DoI: 10.1108/PM-05-2013-0032.

Laura. What is rural gentrification? In collab. with Martin Phillips. RGSIBG 'ask the geographer' podcast series. Aug. 2, 2019.

Lees, Loretta. "Planetary gentrification and urban (re)development". In: Urban Development Issues 61.1 (Apr. 12, 2019), pp. 5-13. DoI: 10.2478/ udi-2019-0001.

Lefebvre, Henri. Au-delà du structuralisme. Shelfmark RN 002477. Paris: Éditions Anthropos, 1971.

Legates, Richard T and Chester Hartman. "The anatomy of displacement in the United States". In: Gentrification of the City. Ed. by Neil Smith and Peter Williams. Social Science Library shelfmark HT170 GEN. Allen \& Unwin, 1986, pp. 178-200. IsBN: 0-04-301201-9.

Lukens, David. "Shifting Roles of the State and the Evolution of Neighborhood Change in Seoul”. PhD thesis. Massachusetts: Clark University, 2019. 178 pp.

Matless, David. Landscape and Englishness. 2nd ed. Reaktion Books, Sept. 15, 2016. 368 pp. ISBN: 978-1-78023-581-3.

Millennium Book. Wolds Life Project, 2000.

Mingay, GE. A Social History of the English Countryside. Shelfmark D42.1 MIN. London: Routledge, 1990. ISBN: 978-0-415-03408-1.

Nelson, Peter B, Alexander Oberg, and Lise Nelson. "Rural gentrification and linked migration in the United States". In: Journal of Rural Studies 26.4 (Oct. 2010), pp. 343-352. IssN: 0743-0167. DoI: $10.1016 / \mathrm{j}$. jrurstud.2010.06.003.

Newby, Howard. The deferential worker: a study of farm workers in East Anglia. Shelfmark 305.56 NEW. London: Allen Lane, 1977. ISBN: 9780-7139-0892-3. 
Nichols, John. The History and Antiquities of the County of Leicester. 1971 reprint. Vol. 3.1. 4 vols. Shelfmark F942 LEI/1 NIC. 1800. 560 pp. ISBN: 0-85409-690-6.

“Packe v Packe-Reading”. In: Leicester Journal and Midland Counties General Advertiser (Apr. 29, 1870). Issue 2791, p. 6.

Packe, Anthony H. Our Founding Ancestor: A Short History of Sir Christopher Packe. Local Records Office reference DE3969/51. 1976.

Phibbs, Tobias. Labour Country. Fabian Society, Mar. 27, 2018.

Phillips, Martin. "Habermas, Rural Studies, and Critical Social Theory". In: Writing the rural: five cultural geographies. Shelfmark 910.2 WRI. London: Chapman, 1994. ISBN: 978-1-85396-197-7.

Phillips, Martin, Paul Cloke, and Nigel Thrift. "The new middle classes and the social constructs of rural living”. In: Social Change and the Middle Classes. Ed. by Tim Butler and Mike Savage. Routledge, Nov. 5, 2013, pp. 220-238. ISBN: 978-1-134-21758-8.

Polanyi, Karl. The Great Transformation: The Political and Economic Origins of Our Time. 2nd edition. Shelfmark D20.981 POL. Boston: Beacon Press, May 10, 2002. 360 pp. ISBN: 978-0-8070-5643-1.

Prestwold Hall listing. Listing number 1000964. Mar. 17, 1986.

"Prestwold in 1800". In: Wolds Historical Organisation (1995). ISsN: 17442931.

Prior, John. Leicestershire in 1777. In collab. with J D Welding. Shelfmark F 942 LEI/5 /PRI. Leicestershire Industrial History Society, 1984. ISBN: 978-0-85022-172-5.

Risager, Bjarke Skærlund. Neoliberalism is a political project. In collab. with David Harvey. Jacobin. July 23, 2016.

Roberts, Brian K. Landscapes of Settlement. Shelfmark 910.9 ROB. Routledge, Mar. 3, 1996. 200 pp. ISBN: 978-0-415-11968-9.

Shaw, Joan and Peter Shaw. "A Wolds Diversion". In: Wolds Historical Organisation (2000), pp. 6-10. ISsN: 1744-2931.

- "Cotes Juxta Lughborowe”. In: Wolds Historical Organisation 2 (2005), pp. 8-10. ISsN: 1744-2931.

Shipley, Peter Samuel. "The Leicestershire Gentry and its Social and Cultural Networks c. 1790-1875”. PhD thesis. University of Leicester, May 2011. 354 pp.

Slater, Tom. "Clarifying Neil Smith's Rent Gap Theory of Gentrification". In: Tracce Urbane 1 (2017). ISSN: 2532-6562. Dor: 10.13133/2532-6562_1.9.

- "Missing Marcuse: On gentrification and displacement". In: City 13.2 (June 2009), pp. 292-311. ISsN: 1360-4813. DOI: 10 . $1080 /$ 13604810902982250 . 
Slater, Tom. "The Eviction of Critical Perspectives from Gentrification Research". In: International Journal of Urban and Regional Research 30.4 (2006), pp. 737-757. ISSN: 1468-2427. DOI: 10.1111/j.1468-2427. 2006. 00689.x.

- What is Gentrification? Gentrification Web. Feb. 2002.

Smith, Adam. An Inquiry into the Nature and Causes of the Wealth of Nations. Ed. by Edwin Cannan. In collab. with George J Stigler. University of Chicago Press, Feb. 15, 1977. 1152 pp. IsBN: 978-0-226-76374-3.

Smith, Henry Stooks. The Parliaments of England. Vol. 1. 3 vols. London: Simpkin, Marshall \& Co., 1844.

Smith, Neil. "Gentrification and the Rent Gap". In: Annals of the Association of American Geographers 77.3 (1987), pp. 462-465. Issn: 00045608.

- The New Urban Frontier: gentrification and the revanchist city. Social Science Library shelfmark HT170 SMI. London: Routledge, 1996. 262 pp. ISBN: 978-0-415-13254-1.

- "Toward a Theory of Gentrification: A Back to the City Movement by Capital, not People". In: Journal of the American Planning Association 45.4 (Oct. 1979), pp. 538-548. ISSN: 0194-4363. DOI: 10.1080/01944367908977002.

Smith, Neil and Michael LeFaivre. "A Class Analysis of Gentrification”. In: Gentrification, Displacement, and Neighborhood Revitalization. Ed. by J John Palen and Bruce London. New York: SUNY Press, 1984, pp. 4363. ISBN: 978-0-87395-784-7.

Sombart, Werner. The Quintessence of Capitalism: a Study of the History and Psychology of the Modern Business Man. Vol. 4 . 7 vols. Routledge, 1930. 398 pp. ISBN: 978-0-415-16724-6.

Stein, Samuel. Capital City: Gentrification and the Real Estate State. Verso, Mar. 5, 2019. 243 pp.

Stephen, Leslie. Dictionary of National Biography. Ed. by Sidney Lee. Vol. 43. 63 vols. London: Elder Smith \& Co., 1895.

Swade, Kate and Mark Walton. "This land is our land". In: Red Pepper 225 (Aug. 2019), pp. 26-29. Issn: 1353-7024.

Sylvanus, Urban. The Gentleman's Magazine. Vol. 7. London: William Pickering, June 1837. 693 pp.

Thompson, FML. Gentrification and the enterprise culture: Britain, 17801980. Shelfmark D42 THO. Oxford University Press, 2001. 200 pp. ISBN: 978-0-19-926560-2.

- ed. Landowners, capitalists, and entrepreneurs. Shelfmark D42 LAN. Oxford University Press, 1994. 312 pp. ISBN: 978-0-19-828301-0. 
Thompson, James. The History of Leicester: from the time of the Romans to the end of the Seventeenth Century. Leicester: Crossley, 1849. 483 pp. ISBN: 978-1-166-33373-7.

Thompson, Thomas. "Loughborough Agricultural Association". In: Leicester Chronicle (Oct. 12, 1839). Issue 1508.

Throsby, John. Select views in Leicestershire. 1789. 353 pp.

Trushaw, Bob. "Thorpe in the Glebe". In: Wolds Historical Organisation 2 (2005), pp. 24-25. IssN: 1744-2931.

Vigdor, Jacob, Douglas S. Massey, and Alice M. Rivlin. "Does Gentrification Harm the Poor?" In: Brookings-Wharton Papers on Urban Affairs (2002), pp. 133-182. IssN: 1528-7084.

Walker, David. "William Burn: the country house in transition". In: Seven Victorian Architects. Ed. by Jane Fawcett. Shelfmark 720.942 SEV. London: Thames and Hudson, 1976, pp. 8-31. IsBN: 978-0-500-34070-7.

Ward, Callum. "The Mobilisation of Land as a Financial Asset". PhD thesis. Katholieke Universiteit Leuven, Apr. 2019. 142 pp.

Ward, Callum and Manuel B Aalbers. "The shitty rent business: What's the point of land rent theory?" In: Urban Studies 53.9 (Mar. 31, 2016), pp. 1760-1783. ISSN: 0042-0980. DOI: 10.1177/0042098016638975.

Williams, Raymond. The Country and the City. Shelfmark 820.9 WIL. London: Chatto \& Windus, 1973. ISBN: 978-0-7012-1005-2.

Wilson, Geoff A. "From Productivism to Post-Productivism... and back again? Exploring the (Un)changed Natural and Mental Landscapes of European Agriculture”. In: Transactions of the Institute of British Geographers 26.1 (2001), pp. 77-102. IssN: 0020-2754.

Wood, Ellen Meiksins. The Origin of Capitalism: A Longer View. Shelfmark 335.1 WOO. Verso, 2002. 216 pp. ISBN: 978-1-85984-392-5.

Yang, Jinkun, Eddie Hui, Wei Lang, and Xun Li. "Land Ownership, RentSeeking, and Rural Gentrification: Reconstructing Villages for Sustainable Urbanization in China”. In: Sustainability 10.6 (June 2018), p. 1997. DoI: 10.3390/su10061997.

Yeginsu, Ceylan and Laetitia Vancon. "This Is All We Can Afford: Shrinking Lives in the English Countryside". In: The New York Times (May 13, 2019). ISSN: 0362-4331.

Where possible, a shelfmark has been provided for books in this bibliography, and unless otherwise noted these refer to locations in the Charles Wilson Library at the University of Leicester. Part of this dissertation was written at the Social Sciences Library in Oxford, and there are shelfmark locations for there also. 
A complete bibfile containing all the references in this bibliography is attached in the prestwold_bibliography.bib st file.

\section{Appendix}

\section{A Annual expenditure on luxury items by the Packe family}

\begin{tabular}{cc} 
Year & Expenses (£) \\
\hline 1833 & 64 \\
1834 & 188 \\
1835 & 168 \\
1836 & 79 \\
1837 & 160 \\
1838 & 341 \\
1839 & 240 \\
1840 & 354 \\
1841 & 353 \\
1842 & 343 \\
1843 & 259 \\
1844 & 680 \\
1845 & 567 \\
1846 & 643 \\
1847 & 604 \\
1849 & 466 \\
1850 & 328 \\
1851 & 389 \\
1852 & 206 \\
1853 & 151 \\
1854 & 196
\end{tabular}

These are the values used to generate the graph in figure 6. The data is also attached in the expenditure_graph.dat $s$ file. Source: DE1346/350. 


\section{B Prestwold population census}

\begin{tabular}{cc} 
Census year & Population \\
\hline 1801 & 747 \\
1811 & 855 \\
1821 & 974 \\
1831 & 942 \\
1841 & 1,043 \\
1851 & 965 \\
1861 & no data \\
1871 & no data \\
1881 & 83 \\
1891 & 87 \\
1901 & 93 \\
1911 & 84 \\
1921 & 81
\end{tabular}

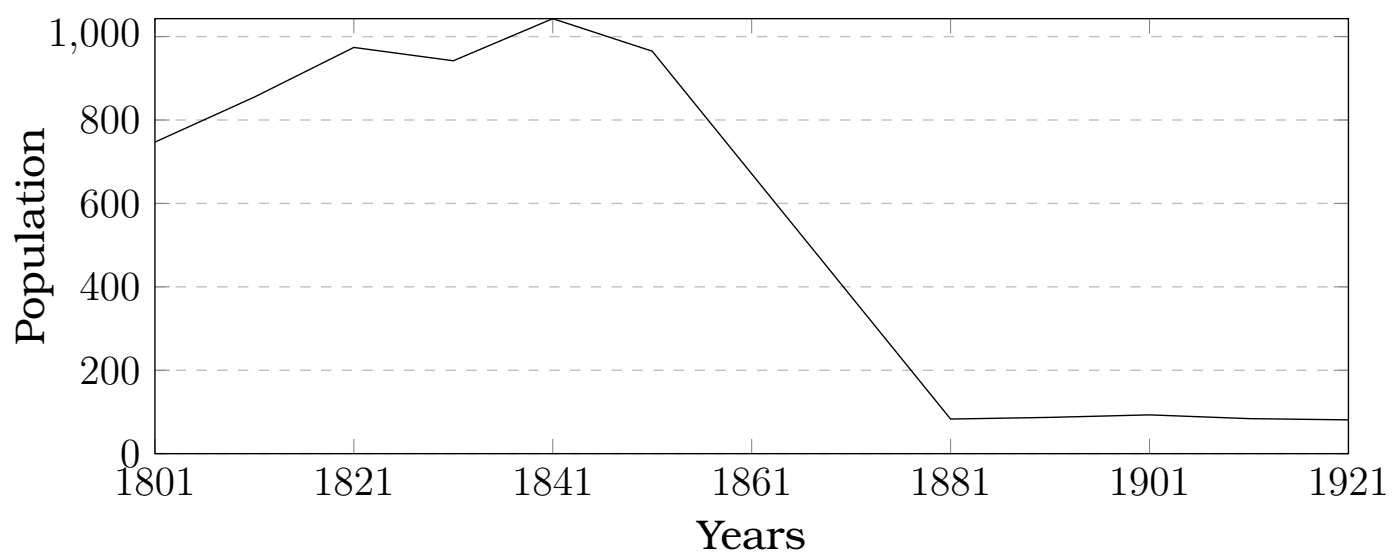

These are the census results for Prestwold parish from 1801 to 1921 . The records are available on the Vision of Britain website at: http://www.visionofbritain.org.uk/unit/10389525/cube/TOT_POP 


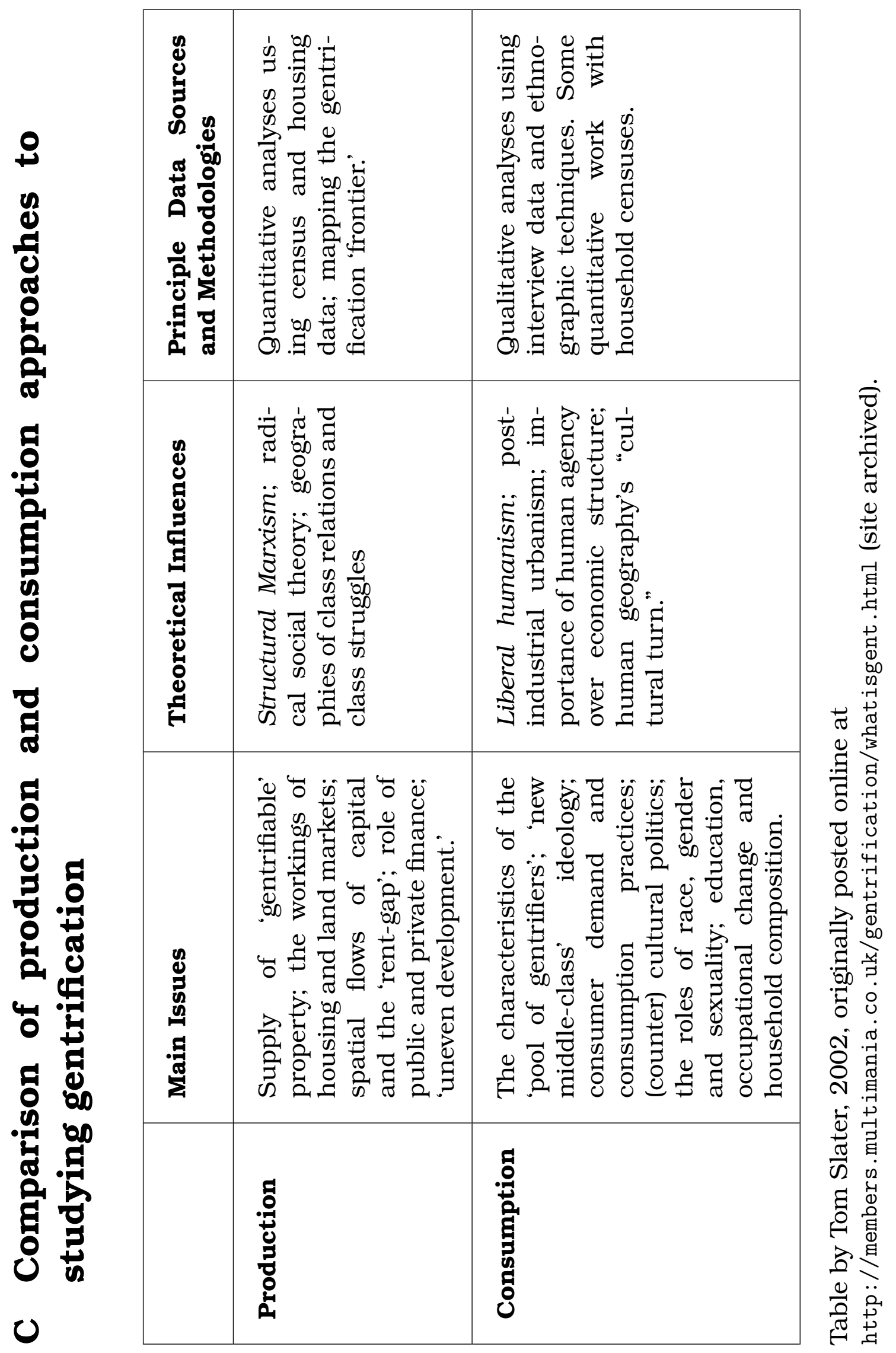

